Publication List

Juntendo Medical Journal

2020. 66 (5), 443-464

\title{
Publications from Juntendo University Graduate School of Medicine, 2018 [3/6]
}

\section{Department of Metabolism \& Endocrinology}

$\langle$ Original Articles〉

1) Yamada $Y$, Terauchi $Y$, Watada $H$, Nakatsuka Y, Shiosakai K, Washio T, Taguchi T: Efficacy and Safety of GPR119 Agonist DS-8500a in Japanese Patients with Type 2 Diabetes: a Randomized, Double-Blind, Placebo-Controlled, 12-Week Study. Adv Ther, 2018; 35: 367-381.

2) Chinzei K, Shimizu A, Mori K, Harada K, Takeda H, Hashizume M, Ishizuka M, Kato N, Kawamori R, Kyo S, Nagata K, Yamane T, Sakuma I, Ohe K, Mitsuishi M: Regulatory Science on AI-based Medical Devices and Systems. Advanced Biomedical Engineering, 2018, 7: 118-123.

3) Osonoi Y, Mita T, Azuma K, Nakajima K, Masuyama A, Goto H, Nishida Y, Miyatsuka T, Fujitani Y, Koike M, Mitsumata M, Watada H: Defective autophagy in vascular smooth muscle cells enhances cell death and atherosclerosis. Autophagy, 2018, 14: 1991-2006.

* 4) Kamitani M, Miyatsuka T, Miura M, Azuma K, Suzuki L, Himuro M, Katahira T, Nishida Y, Fujitani Y, Watada H: Heterogeneity of autophagic status in pancreatic $\beta$ cells under metabolic stress. Biochem Biophys Res Commun, 2018, 496: 328-334.

* 5) Masuyama A, Mita T, Azuma K, Osonoi Y, Nakajima K, Goto H, Nishida Y, Miyatsuka T, Mitsumata M, Watada H: Defective autophagy in vascular smooth muscle cells enhances atherosclerotic plaque instability. Biochem Biophys Res Commun, 2018; 505: 1141-1147.

6) Katakami N, Mita $T$, Irie $Y$, Takahara $M$, Matsuoka TA, Gosho M, Watada H, Shimomura I; Sitagliptin Preventive study of Intima-media thickness Evaluation (SPIKE) Collaborators: Effect of sitagliptin on tissue

An asterisk (*) denotes doctoral works by Japanese students. A dugger $(\dagger)$ denotes doctoral works by non-Japanese students. characteristics of the carotid wall in patients with type 2 diabetes: a post hoc sub-analysis of the sitagliptin preventive study of intimamedia thickness evaluation (SPIKE). Cardiovasc Diabetol, 2018; 17: 24.

7) Araki E, Yamashita S, Arai H, Yokote K, Satoh J, Inoguchi T, Nakamura J, Maegawa H, Yoshioka N, Tanizawa Y, Watada H, Suganami $\mathrm{H}$, Ishibashi S: Effects of Pemafibrate, a Novel Selective PPAR $\alpha$ Modulator, on Lipid and Glucose Metabolism in Patients With Type 2 Diabetes and Hypertriglyceridemia: A Randomized, Double-Blind, PlaceboControlled, Phase 3 Trial. Diabetes Care, 2018; 41: 538-546.

8) Kaku K, Yamada Y, Watada H, Abiko A, Nishida T, Zacho J, Kiyosue A: Safety and efficacy of once-weekly semaglutide vs additional oral antidiabetic drugs in Japanese people with inadequately controlled type 2 diabetes: A randomized trial. Diabetes Obes Metab, 2018; 20: 1202-1212.

9) Kawamori R, Haneda M, Suzaki K, Cheng G, Shiki K, Miyamoto Y, Solimando F, Lee C, Lee $\mathrm{J}$, George J: Empagliflozin as add-on to linagliptin in a fixed-dose combination in Japanese patients with type 2 diabetes: Glycaemic efficacy and safety profile in a $52^{-}$ week, randomized, placebo-controlled trial. Diabetes Obes Metab, 2018; 20: 2200-2209.

10) Irie $Y$, Katakami $N$, Mita $T$, Takahara $M$, Matsuoka TA, Gosho M, Watada H, Shimomura I: Evaluation of the Effect of Alogliptin on Tissue Characteristics of the Carotid Wall: Subanalysis of the SPEAD-A Trial. Diabetes Ther, 2018; 9: 317-329.

11) Mita T, Hiyoshi $T$, Yoshii H, Chimori H, Ikeda K, Sato J, Watada H: Study Protocol for the Initial Choice of DPP-4 Inhibitor in Japanese

This is a reprint of content originally published in Juntendo University HP. 
Patients with Type 2 diabetes Mellitus: Effect of Linagliptin on QOL (INTEL-QOL) Trial. Diabetes Ther, 2018; 9: 1403-1412.

* 12) Miura M, Miyatsuka T, Katahira T, Sasaki S, Suzuki L, Himuro M, Nishida Y, Fujitani Y, Matsuoka TA, Watada, H: Suppression of STAT3 signaling promotes cellular reprogramming into insulin-producing cells induced by defined transcription factors. EBioMedicine, 2018; 36: 358-366.

13) Goto H, Mita T, Fujitani Y, Fujimoto S, Takahashi K, Satoh H, Hirose T, Hiyoshi T, Ai M, Okada Y, Nishimura H, Kuroda H, Matsubara T, Gosho M, Ishii H, Watada H: Effects of linagliptin versus voglibose on treatment-related quality of life in patients with type 2 diabetes: sub-analysis of the L-STEP study. Endocr J, 2018; 65: 657-668.

14) Kurozumi A, Okada $Y$, Satoh $H$, Inoue I, Chimori H, Akita E, Shiraiwa T, Fujitani Y, Mita T, Gosho M, Watada H: Effects of linagliptin monotherapy compared with voglibose on postprandial lipid profiles in Japanese patients with type 2 diabetes: linagliptin study of effects on postprandial blood glucose (L-STEP) sub-study 1. Endocr J, 2018; 65: 415-425.

* 15) Honda A, Komiya K, Hara A, Fukunaka A, Suzuki L, Miyatsuka T, Ogihara T, Fujitani Y, Watada H: Normal pancreatic $\beta$-cell function in mice with Rip-Cre-mediated inactivation of p62/SQSTM1. Endocr J, 2018; 65: 83-89.

16) Tomiyama H, Ohkuma T, Ninomiya T, Mastumoto C, Kario K, Hoshide S, Kita Y, Inoguchi T, Maeda Y, Kohara K, Tabara Y, Nakamura M, Ohkubo T, Watada H, Munakata M, Ohishi M, Ito N, Nakamura M, Shoji T, Vlachopoulos $\mathrm{C}$, Yamashina A; Collaborative group for J-BAVEL-IAD (Japan Brachial-Ankle Pulse Wave Velocity Individual Participant Data Meta-Analysis of Prospective Studies to Examine the Significance of Inter-Arm Blood Pressure Difference): An Individual Participants Data Meta-Analysis. Hypertension, 2018; 71: 1030-1038.

17) Katakami N Mita T, Gosho M, Takahara M, Irie Y, Yasuda T, Matsuoka TA, Osonoi T, Watada H, Shimomura I: Clinical Utility of Carotid Ultrasonography in The Prediction of
Cardiovascular Events in Patients with Diabetes: A Combined Analysis of Data Obtained in Five Longitudinal Studies. J Atheroscler Thromb, 2018; 25: 1053-1066.

18) Shioya-Yamada M, Shimada K, NishitaniYokoyama M, Sai E, Takeno K, Tamura Y, Watada H, Kawamori R, Daida H, Kawai S: Association Between Visceral Fat Accumulation and Exercise Tolerance in Non-Obese Subjects Without Diabetes. J Clin Med Res, 2018; 10: 630-635.

19) Sawada SS, Gando Y, Kawakami R, Blair SN, Lee IM, Tamura Y, Tsuda H, Saito H, Miyachi M: Combined aerobic and resistance training, and incidence of diabetes: $\mathrm{A}$ retrospective cohort study in Japanese older women. J Diabetes Investig, Epub 2018 Dec 18.

20) Terauchi, Y, Yamada, Y, Watada, H, Nakatsuka, Y, Shiosakai, K, Washio, T, Taguchi, T: Efficacy and safety of the G protein-coupled receptor 119 agonist DS-8500a in Japanese type 2 diabetes mellitus patients with inadequate glycemic control on sitagliptin: A phase 2 randomized placebo-controlled study. J Diabetes Investig, 2018; 9: 1333-1341.

21) Furukawa Y, Tamura Y, Takeno K, Funayama T, Kaga H, Suzuki R, Watanabe T, Kakehi S, Kanazawa A, Kawamori R, Watada $\mathrm{H}$ : Impaired peripheral insulin sensitivity in non-obese Japanese patients with type 2 diabetes mellitus and fatty liver. J Diabetes Investig, 2018, 9: 529-535.

22) Sagesaka H, Sato Y, Someya Y, Tamura Y, Shimodaira M, Miyakoshi T, Hirabayashi K, Koike H, Yamashita K, Watada H, Aizawa T: Type 2 Diabetes: When Does It Start? J Endocr Soc, 2018, 2: 476-484.

23) Someya Y, Tamura Y, Suzuki R, Kaga H, Kadowaki S, Sugimoto D, Kakehi S, Funayama T, Furukawa Y, Takeno K, Sato J, Kanazawa A, Kawamori R, Watada H: Characteristics of Glucose Metabolism in Underweight Japanese Women. J Endocr Soc, 2018; 2: 279-289.

*24) Suzuki L, Miyatsuka T, Himuro M, Nishio R, Goto H, Uchida T, Nishida Y, Kanazawa A, Watada H: Everolimus Directly Suppresses Insulin Secretion Independently of Cell Growth Inhibition. J Endocr Soc, 2018, 2: 589-596. 
25) Uesato T, Ogihara $T$, Hara A, Iida $H$, Miyatsuka T, Fujitani Y, Takeda S, Watada $\mathrm{H}$ : Enhanced Expression of the Key Mitosis Regulator Cyclin B1 Is Mediated by PDZBinding Kinase in Islets of Pregnant Mice. J Endocr Soc, 2018; 2: 207-219.

26) Horikawa Y, Enya M, Mabe H, Fukushima K, Takubo N, Ohashi M, Ikeda F, Hashimoto KI, Watada H, Takeda J: NEUROD1-deficient diabetes (MODY6): Identification of the first cases in Japanese and the clinical features. Pediatr Diabetes, 2018; 19: 236-242.

27) Tanaka R, Masuda H, Fujimura S, Ito-Hirano R, Arita K, Kakinuma Y, Hagiwara H, Kado M, Hayashi A, Mita T, Ogawa T, Watada H, Mizuno H, Sawada N, Asahara, T: QualityQuantity Control Culture Enhances Vasculogenesis and Wound Healing Efficacy of Human Diabetic Peripheral Blood CD34 + Cells. Stem Cells Transl Med, 2018; 7: 428-438.

28) Ohkuma T, Ninomiya T, Tomiyama H, Kario K, Hoshide S, Kita Y, Inoguchi T, Maeda Y, Kohara K, Tabara Y, Nakamura M, Ohkubo T, Watada $\mathrm{H}$, Munakata M, Ohishi M, Ito N, Nakamura M, Shoji T, Vlachopoulos C, Aboyans V, Yamashina A; collaborative group for the Japan Brachial-Ankle pulse wave VELocity individual participant data metaanalysis of prospective studies to examine the significance of the Ankle-Brachial Index (J-BAVEL-ABI): Ankle-brachial index measured by oscillometry is predictive for cardiovascular disease and premature death in the Japanese population: An individual participant data meta-analysis. Atherosclerosis, 2018, 275: 141-148.

29) Kosiborod M, Gomes MB, Nicolucci A, Pocock S, Rathmann W, Shestakova MV, Watada H, Shimomura I, Chen H, Cid-Ruzafa J, Fenici P, Hammar N, Surmont F, Tang F, Khunti K, investigators D: Vascular complications in patients with type 2 diabetes: prevalence and associated factors in 38 countries (the DISCOVER study program). Cardiovasc Diabetol, 2018, 17: 150.

30) Kanda E, Kashihara N, Matsushita K, Usui T, Okada H, Iseki K, Mikami K, Tanaka T, Wada T, Watada H, Ueki K, Nangaku M; Research Working Group for Establishing Guidelines for Clinical Evaluation of Chronic Kidney Disease: Guidelines for clinical evaluation of chronic kidney disease: AMED research on regulatory science of pharmaceuticals and medical devices. Clin Exp Nephrol, 2018; 22: 1446-1475.

31) Katakami N, Mita T, Takahara M, Hashigami K, Kawashima M, Shimomura I, Watada H; J-Discover study group: Rationale and Design for the J-DISCOVER Study: DISCOVERing the Treatment Reality of Type 2 Diabetes in a Real-World Setting in Japan-A Protocol. Diabetes Ther, 2018; 9: 165-175.

32) Katahira T, Kanazawa A, Shinohara M, Koshibu M, Kaga H, Mita T, Tosaka Y, Komiya K, Miyatsuka T, Ikeda F, Azuma K, Takayanagi N, Ogihara T, Ohmura C, Miyachi A, Mineo E, Yamashita S, Watada H: Postprandial Plasma Glucagon Kinetics in Type 2 Diabetes Mellitus: Comparison of Immunoassay and Mass Spectrometry. J Endocr Soc, 2018; 3: 42-51.

33) Watada H, Shiramoto M, Ueda S, Tang W, Asano M, Thoren F, Kim H, Yajima T, Boulton DW, Araki E: Pharmacokinetics and pharmacodynamics of dapagliflozin in combination with insulin in Japanese patients with type 1 diabetes. Diabetes Obes Metab, Epub 2018 Dec 21.

34) Taira M, Imamura M, Takahashi A, Kamatani Y, Yamauchi T, Araki SI, Tanaka N, van Zuydam NR, McCarthy M, Ahlqvist E, Toyoda M, Umezono T, Kawai K, Imanishi M, Watada H, Suzuki D, Maegawa H, Babazono T, Kaku K, Kawamori R, SUMMIT Consortium; Leif C Groop, Kadowaki T, Maeda S: A variant within the FTO confers susceptibility to diabetic nephropathy in Japanese patients with type 2 diabetes. PLoS One, 2018; 13: e0208654.

〈Reviews〉

1) Fink J, Matsumoto M, Tamura Y: Potential application of testosterone replacement therapy as treatment for obesity and type 2 diabetes in men. Steroids, 2018; 138: 161-166.

\section{Department of Nephrology}

〈Original Articles〉

1) Shimizu M, Furuichi K, Toyama T, Funamoto 
T, Kitajima S, Hara A, Ogawa D, Koya D, Ikeda K, Koshino Y, Kurokawa Y, Abe H, Mori K, Nakayama M, Konishi Y, Samejima KI, Matsui M, Yamauchi H, Gohda T, Fukami K, Nagata D, Yamazaki H, Yuzawa Y, Suzuki Y, Fujimoto S, Maruyama S, Kato S, Naito T, Yoshimura K, Yokoyama H, Wada T: Decline in estimated glomerular filtration rate is associated with risk of end-stage renal disease in type 2 diabetes with macroalbuminuria: an observational study from JDNCS. Clin Exp Nephrol, 2018; 22: 377-387.

2) Suzuki H, Yasutake J, Makita Y, Tanbo Y, Yamasaki K, Sofue T, Kano T, Suzuki Y: IgA nephropathy and IgA vasculitis with nephritis have a shared feature involving galactosedeficient IgA1-oriented pathogenesis. Kidney Int, 2018; 93: 700-705.

3) Ohsawa I, Honda D, Hisada A, Inoshita H, Onda-Tsueshita K, Mano S, Sato N, Nakamura Y, Shimizu T, Gotoh H, Goto Y, Suzuki Y, Tomino Y: Clinical Features of Hereditary and Mast Cell-mediated Angioedema Focusing on the Differential Diagnosis in Japanese Patients. Intern Med, 2018; 57: 319-324.

4) Hamada C, Nakamoto H, Suzuki Y: Morphologic characteristics of macroscopic peritoneal finding in patients with peritoneal dialysis. J Artif Organs, 2018; 21: 102-109.

5) Asao R, Seki $T$, Takagi $M$, Yamada $H$, Kodama F, Hosoe-Nagai Y, Tanaka E, Trejo JAO, Yamamoto-Nonaka K, Sasaki Y, Hidaka T, Ueno T, Yanagita M, Suzuki Y, Tomino Y, Asanuma K: Rac1 in podocytes promotes glomerular repair and limits the formation of sclerosis. Sci Rep, 2018; 8: 5061.

6) Placzek WJ, Yanagawa H, Makita Y, Renfrow MB, Julian BA, Rizk DV, Suzuki Y, Novak J, Suzuki H: Serum galactose-deficient-IgA1 and $\operatorname{IgG}$ autoantibodies correlate in patients with IgA nephropathy. PLoS One, 2018; 13: e0190967.

7) Taguchi K, Yamagishi S, Yokoro M, Ito S, Kodama G, Kaida Y, Nakayama Y, Ando R, Yamada-Obara N, Asanuma K, Matsui T, Higashimoto Y, Brooks CR, Ueda S, Okuda S, Fukami K: RAGE-aptamer attenuates deoxycorticosterone acetate/salt-induced renal injury in mice. Sci Rep, 2018; 8: 2686.
8) Yamamoto R, Imai E, Maruyama S, Yokoyama $\mathrm{H}$, Sugiyama $\mathrm{H}$, Nitta K, Tsukamoto $\mathrm{T}$, Uchida S, Takeda A, Sato T, Wada T, Hayashi H, Akai Y, Fukunaga M, Tsuruya K, Masutani K, Konta T, Shoji T, Hiramatsu T, Goto S, Tamai H, Nishio S, Shirasaki A, Nagai K, Yamagata K, Hasegawa H, Yasuda H, Ichida S, Naruse T, Fukami K, Nishino T, Sobajima H, Tanaka S, Akahori T, Ito T, Yoshio T, Katafuchi R, Fujimoto S, Okada H, Ishimura E, Kazama JJ, Hiromura K, Mimura T, Suzuki S, Saka Y, Sofue T, Suzuki Y, Shibagaki Y, Kitagawa K, Morozumi K, Fujita Y, Mizutani M, Shigematsu T, Kashihara N, Sato H, Matsuo S, Narita I, Isaka Y: Regional variations in immunosuppressive therapy in patients with primary nephrotic syndrome: the Japan nephrotic syndrome cohort study. Clin Exp Nephrol, 2018; 22: 1266-1280.

9) Gohda T, Nishizaki Y, Murakoshi M, Nojiri S, Yanagisawa N, Shibata T, Yamashita M, Tanaka K, Yamashita Y, Suzuki Y, Kamei N: Clinical predictive biomarkers for normoalbuminuric diabetic kidney disease. Diabetes Res Clin Pract, 2018; 141: 62-68.

10) Honda D, Ohsawa I, Shimizu Y, Maiguma M, Hidaka T, Suzuki H, Io H, Mano S, Takahara H, Rinno H, Tomino Y, Suzuki Y: Suffocation due to Acute Airway Edema in a Patient with Hereditary Angioedema Highlighted the Need for Urgent Improvements in Treatment Availability in Japan. Intern Med, 2018; 57: 3193-3197.

11) Kaifu $K$, Ueda $S$, Nakamura $N$, Matsui $T$, Yamada-Obara N, Ando R, Kaida Y, Nakata M, Matsukuma-Toyonaga M, Higashimoto Y, Fukami K, Suzuki Y, Okuda S, Yamagishi SI: Advanced glycation end products evoke inflammatory reactions in proximal tubular cells via autocrine production of dipeptidyl peptidase-4. Microvasc Res, 2018; 120: 90-93.

12) Kubo A, Shirato I, Hidaka T, Takagi M, Sasaki Y, Asanuma K, Ishidoh K, Suzuki Y: Expression of Cathepsin L and Its Intrinsic Inhibitors in Glomeruli of Rats With Puromycin Aminonucleoside Nephrosis. J Histochem Cytochem, 2018; 66: 863-877.

13) Ikeda M, Terawaki H, Kanda E, Furuya M, Tanno Y, Nakao M, Maruyama Y, Maeda M, 
Higuchi C, Sakurada T, Kaneko T, Io H, Hashimoto K, Ueda A, Hirano K, Washida N, Yoshida H, Yoshikawa K, Taniyama Y, Harada K, Matsuo N, Okido I, Yokoo T: Interventional nephrology: current status and clinical impact in Japan. Clin Exp Nephrol, 2018; 22: 437-447.

14) Suzuki H: Can Biomarkets Help in the Diagnosis and Management of IgAN? Kidney Dis, 2018; 4: 186-187.

15) Suzuki Y: B Cells in IgAN and the Rationale for B Cell Directed Therapies in IgAN. Kidney Dis, 2018; 4: 188-189.

16) Io H, Suzuki Y: Strategy for Prevention of Left Ventricular Remodeling in Predialysis and Dialysis Patients. Contrib Nephrol, 2018; 196: 13-21.

17) Thaha M, Empitu MA, Kadariswantiningsih IN, Nugroho CW, Hasanatulidhhiyah N, Rasyid H, Hakim ZEI, Suryansyah MM, Alda RR, Alsagaff MY, Amin M, Santoso D, Suzuki Y: Anthropometry-based Body Fat Percentage Predicts High hs-CRP in Chronic Kidney Disease Patients. The Indonesian Biomedical Journal, 2018; 10: 184-191.

18) Kamei N, Yamashita M, Nishizaki Y, Yanagisawa N, Nojiri S, Tanaka K, Yamashita Y, Shibata T, Murakoshi M, Suzuki Y, Gohda T: Association between circulating tumor necrosis factor-related biomarkers and estimated glomerular filtration rate in type 2 diabetes. Sci Rep, 2018; 8: 15302.

19) Inoue $M$, Yamamotoya $T$, Nakatsu $Y$, Ueda $K$, Inoue Y, Matsunaga Y, Sakoda H, Fujishiro M, Ono H, Morii K, Sasaki K, Masaki T, Suzuki Y, Asano T, Kushiyama K: The Xanthine Oxidase Inhibitor Febuxostat Suppresses the Progression of IgA Nephropathy, Possibly via Its Anti-Inflammatory and AntiFibrotic Effects in the gddY Mouse Model. Int J Mol Sci, 2018; 19: 3967.

*20) Takahashi K, Ueda K, Kobayashi T, Nishiyama A, Fujisawa T, Sugaya T, Shiota S, Takahashi K, Gohda T, Horikoshi S, Suzuki Y: Chronic intermittent hypoxia-mediated renal sympathetic nerve activation in hypertension and cardiovascular disease. Sci Rep, 2018; 8: 17926.

21) Yamasaki K, Suzuki H, Yasutake J, Yamasaki
Y, Suzuki Y: Galactose-Deficient IgA1-Specific Antibody Recognizes GalNAc-Modified Unique Epitope on Hinge Region of IgA1. Monoclon Antib Immunodiagn Immunother, 2018; 37: 252-256.

〈Reviews〉

1) Gohda T, Suzuki H, Hidaka T, Ueda S, Suzuki Y: An Update of Pathogenesis and Treatment in Patients with Chronic Kidney Disease (CKD) and Cardio-Renal Syndrome. Juntendo Medical Journal, 2018; 64: 227-234.

2) Suzuki H, Suzuki Y: Murine Models of Human IgA Nephropathy. Semin Nephrol, 2018; 38: 513-520.

\section{Department of Obstetrics and Gynecology}

〈Original Articles〉

1) Okumura T, Muronosono E, Tsubuku M, Terao Y, Takeda S, Maruyama M: Anaplastic carcinoma in ovarian seromucinous cystic tumor of borderline malignancy. J Ovarian Res, 2018; 11: 77.

2) Aoki Y, Kanao H, Kikuchi I, Nomura H, Okamoto S, Hisa T, Sugihara T, Kitano R, Omatsu $\mathrm{K}$, Tanigawa T, Takeshima N: Comparison of the Technical Feasibility and Safety of Three Contained Morcellation Techniques: A Pilot Study in an Animal Model J Minim Invasive Gynecol. J Minim Invasive Gynecol, Epub 2018 Dec 16.

3) Kikuchi I, Kagawa N, Shirosaki Y, Shinozaki I, Miyakuni Y, Oshina K, Nojima M, Yoshida K: Early outcomes of a municipally funded oocyte cryopreservation programme in Japan. Hum Fertil (Camb), Epub 2018 Apr 19.

* 4) Takahashi M, Takeda J, Ono Y, Nagai T, Seki $\mathrm{H}$, Takeda S: Safety and reliability of forceps delivery based on a 3-dimensional fetal head evaluation: a retrospective study. Hypertension Research in Pregnancy, 2017; 5: 65-72.

5) Okada H, Kuroda Y, Amano K, Kikuchi T, Matsuoka S, Ogishima D: Recurrent spontaneous cervical epidural hematoma in a parturient 11 hours after vaginal delivery without labor epidural analgesia. Int J Obstet Anesth, 2018; 35: 108-109.

6) Uesato $T$, Ogihara $T$, Hara $A$, Iida $H$, Miyatsuka T, Fujitani Y, Takeda S, Watada H: Enhanced Expression of the Key Mitosis 
Regulator Cyclin B1 Is Mediated by PDZBinding Kinase in Islets of Pregnant Mice. J Endocr Soc, 2018; 2: 207-219.

* 7) Ikemoto Y, Kuroda K, Nakagawa K, Ochiai A, Ozaki R, Murakami K, Jinushi M, Matsumoto A, Sugiyama R, Takeda S: Vitamin D regulates maternal $\mathrm{T}$-helper cytokine production in infertile women. Nutrients, 2018: 10: 902.

8) Ikemoto Y, Kuroda K, Ochiai A, Yamashita S, Ikuma S, Nojiri S, Itakura A, Takeda S: Prevalence and risk factors of zygotic splitting after 937848 single embryo transfer cycles. Hum Reprod, 2018; 33: 1984-1991.

9) Kusunoki S, Terao Y, Hirayama T, Fujino K, Ujihira T, Ota T, Takeda S: Safety and efficacy of neoadjuvant chemotherapy with bevacizumab in advanced-stage peritoneal/ ovarian cancer patients. Taiwan J Obstet Gynecol, 2018; 57: 650-653.

10) Horie K, Inoue K, Suzuki S, Adachi S, Yada S, Hirayama T, Hidema S, Young LJ, Nishimori $\mathrm{K}$ : Oxytocin receptor knockout prairie voles generated by CRISPR/Cas9 editing show reduced preference for social novelty and exaggerated repetitive behaviors. Horm Behav, Epub 2018 Nov 8.

11) Watanabe $K$, Matsubara $K$, Nakamoto $O$, Ushijima J, Ohkuchi A, Koide K, Makino S, Mimura K, Morikawa M, Naruse K, Tanaka K, Nohira T, Metoki H, Takeda S, Seki H, Takagi K, Yamasaki M, Ichihara A, Kimura $\mathrm{T}$, Saito S: Outline of the new definition and classification of "Hypertensive Disorders of Pregnancy (HDP)"; a revised JSSHP statement of 2005. Hypertension Research in Pregnancy, 2018; 6: 33-37.

12) Hirashima $C$, Takahashi K, Saito S, Seki H, Watanebe K, Naruse K, Makino S, Metoki H, Matsubara S, Ichihara A, Ohkuchi A: Pregnancy outcomes in Japanese pregnant women with either chronic hypertension or white coat hypertension (JP-WCH): protocol for a prospective multicenter cohort study. Hypertension Research in Pregnancy, 2018; 6: 7-10.

13) Harada A, Miyashita S, Nagai R, Makino S, Murotsuki J: Prenatal Sonographic Findings and Prognosis of Craniosynostosis Diagnosed during the Fetal and Neonatal Periods.
Congenit Anom (Kyoto), Epub 2018 Sep 5.

14) Inoue $R$, Sumikura $H$, Kumagai $A$, Kato $N$, Makino S, Itakura A: Successful management of obstetric disseminated intravascular coagulation using a portable fibrinogenmeasuring device. J Obstet Gynaecol Res, 2018; 44: 788-791.

15) Murakami K, Yamamoto Y, Fukunaga H, Matsushita M, Hirai C, Makino S, Shimizu T, Itakura A, Takeda S: Predictive markers and prenatal management of isolated fetal complete atrioventricular block: A retrospective review at a single institution. J Obstet Gynaecol Res, 2018; 44: 228-233.

16) Suzuki T, Behnam M, Ronasian F, Salehi M, Shiina M, Koshimizu E, Fujita A, Sekiguchi F, Miyatake S, Mizuguchi T, Nakashima M, Ogata K, Takeda S, Matsumoto N, Miyake N: A homozygous NOP14 variant is likely to cause recurrent pregnancy loss. J Hum Genet, 2018; 63: 425-430.

17) Takata A, Miyake N, Tsurusaki Y, Fukai R, Miyatake S, Koshimizu E, Kushima I, Okada T, Morikawa M, Uno Y, Ishizuka K, Nakamura K, Tsujii M, Yoshikawa T, Toyota T, Okamoto N, Hiraki Y, Hashimoto R, Yasuda Y, Saitoh S, Ohashi K, Sakai Y, Ohga S, Hara T, Kato M, Nakamura K, Ito A, Seiwa C, Shirahata E, Osaka H, Matsumoto A, Takeshita S, Tohyama J, Saikusa T, Matsuishi T, Nakamura T, Kato T, Suzuki T, Saitsu H, Nakashima M, Mizuguchi T, Tanaka F, Mori $\mathrm{N}$, Ozaki N, Matsumoto N: Integrative analyses of de novo mutations provide deeper biological insights in autism spectrum disorder. Cell Rep, 2018; 22: 734-747.

18) Kuroda M, Kuroda K, Segawa T, Noh JY, Yoshihara A, Koichi Ito K, Osada H, Takeda S, Teramoto S: Levothyroxine supplementation improves serum anti-Müllerian hormone levels in infertile patients with Hashimoto's thyroiditis. J Obstet Gynaecol Res, 2018; 44: 739-746.

19) Ono $Y$, Murayama $Y$, Era S, Matsunaga S, Nagai T, Osada H, Takai Y, Baba K, Takeda S, Seki H: Study of the utility and problems of common iliac artery balloon occlusion for placenta previa with accrete. J Obstet Gynaecol Res, 2018; 44: 456-462. 
20) Sano Y, Hirai C, Makino S, Li X, Takeda J, Itakura A, Takeda S: Incidence and risk factors of severe lacerations during forceps delivery in a single teaching hospital where simulation training is held annually. J Obstet Gynaecol Res, 2018; 44: 708-716.

21) Hasegawa J, Ikeda T, Toyokawa S, Jojima E, Satoh S, Ichizuka K, Tamiya N, Nakai A, Fujimori K, Maeda T, Masuzaki H, Takeda S, Suzuki H, Ueda S, Ikenoue T; Prevention Recurrence Committee, Japan Obstetric Compensation System for Cerebral Palsy: Relevant obstetric factors associated with fetal heart rate monitoring for cerebral palsy in pregnant women with hypertensive disorder of pregnancy. J Obstet Gynaecol Res, 2018; 44: 647-654.

22) Takeda J, Hiranuma K, Hirayama T, Makino S, Itakura A, Takeda S: The use of medial, wider vertical compression sutures to reduce uterine blood flow for effaced uterine isthmus: a case report. J Obstet Gynaecol, 2018; 38: 871-873.

23) Kuroda K, Ezoe K, Kato K, Yabuuchi A, Segawa T, Kobayashi T, Ochiai A, Katoh N, Takeda S: Infertility treatment strategy involving combined freeze-all embryos and single vitrified-warmed embryo transfer during hormonal replacement cycle for in vitro fertilization of women with hypogonadotropic hypogonadism. J Obstet Gynaecol Res, 2018; 44: 922-928.

24) Watanabe K, Matsubara K, Nakamoto O, Ushijima J, Ohkuchi A, Koide K, Makino S, Mimura K, Morikawa M, Naruse K, Tanaka K, Nohira T, Metoki H, Takeda S, Seki H, Takagi K, Yamasaki M, Ichihara A, Kimura T, Saito S: New definition and classification of "Hypertensive Disorders of Pregnancy (HDP)". Hypertension Research in Pregnancy, 2017; 5: 39-40.

25) Takeda J, Ando H, Makino S, Itakura A, Takeda S: Fallible pitfalls for novice obstetrician on application of Naegele forceps. Video J Clin Res, 2018; 1: 100001VAM08JT2018.

26) Matsuda Y, Cho O, Sugita T, Ogishima D, Takeda S: Culture Supernatants of Lactobacillus gasseri and L. Crispatus Inhibit Candida albicans Biofilm Formation and Adhesion to
HeLa Cells. Mycopathologia, 2018; 183: 691700 .

27) Takeda J, Makino S, Hirai C, Shimanuki Y, Inagaki T, Itakura A, Takeda S: Long-term uterine balloon tamponade for treatment and obliterationof ruptured uterine pseudoaneurysm. Taiwan J Obstet Gynecol, 2018; 57: 329-331.

28) Takeda J, Makino S, Matsumura Y, Itakura A, Takeda S: Enclosing sutures technique for control of local bleeding in a case of placenta increta. J Obstet Gynaecol Res, 2018; 44: 1472-1475.

29) Kusunoki S, Fujino K, Hirayama T, Ota T, Terao Y, Itakura A, Takeda S: Primary Vaginal Small-Cell Carcinoma Treated with Concurrent Chemoradiotherapy and Interstitial Irradiation: A Case Report and Review of the Literature. Journal of Gynecologic Surgery, 2018 Journal of Gynecologic Surgery, 2018: 34: 315-318.

30) Shiozawa M, Chang CH, Huang YC, Chen YC, Chi MS, Hao HC, Chang YC, Takeda S, Chi $\mathrm{KH}$, Wang YS: Pharmacologically upregulated carcinoembryonic antigen-expression enhances the cytolytic activity of geneticallymodified chimeric antigen receptor NK-92MI against colorectal cancer cells. BMC Immunol, 2018; 19: 27.

31) Tanaka A, Suzuki K, Nagayoshi M, Tanaka A, Takemoto Y, Watanabe S, Takeda S, Irahara M, Kuji N, Yamagata Z, Yanagimachi R: Ninety babies born after round spermatid injection into oocytes: survey of their development from fertilization to 2 years of age. Fertil Steril, 2018; 110: 443-451.

32) Katoh N, Kuroda K, Tomikawa J, OgataKawata H, Ozaki R, Ochiai A, Kitade M, Takeda S, Nakabayashi K, Hata K: Reciprocal changes of H3K27ac and H3K27me3 at the promoter regions of the critical genes for endometrial decidualization. Epigenomics, 2018; 10: 1243-1257.

33) Nagai S, Ikeda K, Horie-Inoue K, Takeda S, Inoue $\mathrm{S}$ : Estrogen signaling increases nuclear receptor subfamily 4 group A member 1 expression and energy production in skeletal muscle cells. Endocr J, 2018; 65: 1209-1218.

34) Yorifuji T, Takeda J, Makino S, Tanaka T, 
Itakura A, Takeda S: Evaluation of the effectiveness of metreurynters for balloon tamponade. Hypertension Research in Pregnancy, 2018; 6: 26-29.

35) Takeda S: Education and training approaches for reducing maternal deaths in Japan. Hypertension Research in Pregnancy, 2018; 6: 15-19.

36) Suzuki S, Taked S, Okano T, Kinoshita K: Recent strategies in perinatal mental health care in Japan. Hypertension Research in Pregnancy, 2018; 6: 11-14.

37) Kusunoki S, Terao Y, Hirayama T, Fujino K, Ujihira T, Ota T, Takeda S: Safety and efficacy of neoadjuvant chemotherapy with bevacizumab in advanced-stage peritoneal/ ovarian cancer patients. Taiwan J Obstet Gynecol, 2018; 57: 650-653.

38) Wataru Sato, Kazuhiro Ikeda, Tomohiko Urano, Yayoi Abe, Norie Nakasato, Kuniko Horie-Inoue, Satoru Takeda: Efp promotes in vitro and in vivo growth of endometrial cancer cells along with the activation of nuclear factor- $\kappa \mathrm{B}$ signaling. PLoS One, 2018; 13: e0208351.

39) Kawasaki K, Kondoh E, Chigusa Y, Kawamura Y, Mogami H, Takeda S, Horie A, Baba T, Matsumura N, Mandai M, Konishi I: Metabolomic Profiles of Placenta in Preeclampsia. Hypertension, Epub 2018 Dec 31.

40) Satoru Takeda: The 43rd Annual Congress of Japanese College of Surgeons: A Report. Juntendo Medical Journal, 2018; 64: 418-421.

〈Reviews〉

1) Kumagai A, Itakura A, Koya D, Kanasaki K: AMP-Activated Protein (AMPK) in Pathophysiology of Pregnancy Complications. Int J Mol Sci, 2018; 19: 3076.

〈Books〉

1) Ota T, Kaneda H: Temporary Endovascular Balloon Occlusion of the Internal Iliac Arteries to Prevent Hemorrhage During Uterine Cervical Myomectomy. In: Takeda S, Kuwatsuru R, eds. Gynecologic and Obstetric Prophylactic Hemostasis by Intra-arterial Balloon Occlusion. Singapore: Springer, 2018: 23-31.

2) Kuroda K: Chapter 1: Unexplained Infertility: Introduction. In: Kuroda K, Takeda S,
Brosens JJ, Quenby S, eds. Treatment Strategy for Unexplained Infertility and Recurrent Miscarriage. Singapore: Springer, 2018: 3-5.

3) Yamaguchi T, Kuroda K, Tanaka A, Watanabe S: Chapter 2: Fertilization Failure. In: Kuroda K, Takeda S, Brosens JJ, Quenby S, eds. Treatment Strategy for Unexplained Infertility and Recurrent Miscarriage. Singapore: Springer, 2018: 7-17.

4) Ikemoto $Y$, Kuroda K, Kuribayashi $Y$, Inoue M: Chapter 3: Tubal Function Abnormalities with Tubal Patency in Unexplained Infertility. In: Kuroda K, Takeda S, Brosens JJ, Quenby S, eds. Treatment Strategy for Unexplained Infertility and Recurrent Miscarriage. Singapore: Springer, 2018: 19-31.

5) Kuroda K, Yamashita S: Chapter 4: Implantation Failure 1: Intrauterine Circumstances and Embryo-Endometrium Synchrony at Implantation. In: Kuroda K, Takeda S, Brosens JJ, Quenby S, eds. Treatment Strategy for Unexplained Infertility and Recurrent Miscarriage. Singapore: Springer, 2018: 33-43.

6) Nakagawa K, Sugiyama R: Chapter 5 : Implantation Failure 2: Immunomodulating Treatment for the Patients with Repeated Implantation Failures Caused by Immunological Rejection. In: Kuroda K, Takeda S, Brosens JJ, Quenby S, eds. Treatment Strategy for Unexplained Infertility and Recurrent Miscarriage. Singapore: Springer, 2018: 45-60.

7) Kuroda K, Ochiai A: Chapter 6: Unexplained Infertility: Treatment Strategy for Unexplained Infertility. In: Kuroda K, Takeda S, Brosens JJ, Quenby S, eds. Treatment Strategy for Unexplained Infertility and Recurrent Miscarriage. Singapore: Springer, 2018: 6175.

8) Kuroda K: Chapter 7: Unexplained Recurrent Miscarriage: Introduction. In: Kuroda K, Takeda S, Brosens JJ, Quenby S, eds. Treatment Strategy for Unexplained Infertility and Recurrent Miscarriage. Singapore: Springer, 2018: 79-84.

9) Kuroda K: Chapter 8: Previous Trial Studies of Unexplained Recurrent Miscarriage. In: Kuroda K, Takeda S, Brosens JJ, Quenby S, eds. Treatment Strategy for Unexplained Infertility and Recurrent Miscarriage. 
Singapore: Springer, 2018: 85-94.

10) Kuroda K: Chapter 9: Lifestyle Habits and Pregnancy Loss. In: Kuroda K, Takeda S, Brosens JJ, Quenby S, eds. Treatment Strategy for Unexplained Infertility and Recurrent Miscarriage. Singapore: Springer, 2018: 95104.

11) Murakami K, Kuroda K, Brosens JJ: Chapter 10: Perturbation of Endometrial Decidualization. In: Kuroda K, Takeda S, Brosens JJ, Quenby S, eds. Treatment Strategy for Unexplained Infertility and Recurrent Miscarriage. Singapore: Springer, 2018: 105-114.

12) Kuroda K: Chapter 11: Treatment Strategy for Unexplained Recurrent Miscarriage. In: Kuroda K, Takeda S, Brosens JJ, Quenby S, eds. Treatment Strategy for Unexplained Infertility and Recurrent Miscarriage. Singapore: Springer, 2018: 115-125.

13) Saito $T$, Yamagishi $Y$, Sakanashi K, Tanaka $T$, Kitamura T: Chapter Eight: Personality correlates of perinatal depression and bonding disorders: A study in Kumamoto. In: Kitamura T, Ohashi Y, eds. Perinatal Bonding Disorders: Causes and Consequences. Cambridge: Cambridge Scholars Publishing, 2019: 189-211.

14) Kato H, Kuwatsuru R: Anatomy of Uterine Blood Supply and the Prevention of Massive Hemorrhage. In: Takeda S, Kuwatsuru R, eds. Gynecologic and Obstetric Prophylactic Hemostasis by Intra-arterial Balloon Occlusion. Springer Singapore, 2018: 1-6.

15) Shiraishi A: Application and Methods of the Arterial Balloon Occlusion for the Prophylaxis of Massive Hemorrhage in Gynecologic Fields. In: Takeda S, Kuwatsuru R, eds. Gynecologic and Obstetric Prophylactic Hemostasis by Intra-arterial Balloon Occlusion. Springer Singapore, 2018: 7-8.

16) Kyogoku S: Application and Methods of Arterial Embolization for Prophylaxis and Treatment of Massive Hemorrhage in Obstetric Fields. In: Takeda S, Kuwatsuru R, eds. Gynecologic and Obstetric Prophylactic Hemostasis by Intra-arterial Balloon Occlusion. Springer Singapore, 2018: 9-21.

17) Ota T, Kaneda H: Temporary Endovascular Balloon Occlusion of the Internal Iliac Arteries to Prevent Hemorrhage During Uterine Cervical Myomectomy. In: Takeda S, Kuwatsuru R, eds. Gynecologic and Obstetric Prophylactic Hemostasis by Intra-arterial Balloon Occlusion. Springer Singapore, 2018: 23-31.

18) Takeda J, Makino S: Temporary Arterial Balloon Occlusion for Obstetrical Field. In: Takeda S, Kuwatsuru R, eds. Gynecologic and Obstetric Prophylactic Hemostasis by Intraarterial Balloon Occlusion. Springer Singapore, 2018: 33-39.

19) Takeda S: 1 New Concept of Fetal Station Based on the Trapezoidal Plane (T-Station). In: Takeda S, ed. New Assessment of Fetal Descent and Forceps Delivery. Springer Singapore, 2018: 1-8.

20) Seki, H, Takeda S: 2 Properties and Characteristics of Forceps Delivery. In: Takeda S, ed. New Assessment of Fetal Descent and Forceps Delivery. Springer Singapore, 2018: 9-13.

21) Takeda J, Takeda S: 3 Techniques for the Forceps Procedure. In: Takeda S, ed. New Assessment of Fetal Descent and Forceps Delivery. Springer Singapore, 2018: 15-28.

22) Makino S, Takeda J, Takeda S: 4 UTokyo Kielland Forceps. In: Takeda S, ed. New Assessment of Fetal Descent and Forceps Delivery. Springer Singapore, 2018: 29-36.

23) Itakura A: 5 Education. In: Takeda $S$, ed. New Assessment of Fetal Descent and Forceps Delivery. Springer Singapore, 2018: 37-39.

\section{Department of Hematology}

〈Original Articles〉

1) Watanabe N, Takaku T, Takeda K, Shirane S, Toyota T, Koike M, Noguchi M, Hirano T, Fujiwara H, Komatsu N: Dasatinib-induced anti-leukemia cellular immunity through a novel subset of CD57 positive helper/cytotoxic CD4 $\mathrm{T}$ cells in chronic myelogenous leukemia patients. Int J Hematol, 2018; 108: 588-597.

2) Watanabe N, Kitahara H, Iwao N, Ohta $Y$, Koike M, Komatsu N: Retroperitoneal relapse in an older patient with multiple myeloma during pomalidomide and dexamethasone treatment. Geriatr Gerontol Int, 2018; 
18: $977-979$.

3) Tsuchiya K, Tabe Y, Ai T, Ohkawa T, Usui K, Yuri M, Misawa S, Morishita S, Takaku T, Kakimoto A, Yang H, Matsushita H, Hanami T, Yamanaka Y, Okuzawa A, Horii T, Hayashizaki Y, Ohsaka A: Eprobe mediated RT-qPCR for the detection of leukemia-associated fusion genes. PLoS One, 2018; 13: $\mathrm{e} 0202429$.

4) Tokuhira M, Kimura Y, Sugimoto K, Nakazato T, Ishikawa M, Fujioka I, Takaku T, Iriyama N, Sato E, Fujita H, Hatta Y, Komatsu N, Asou N, Kizaki M, Kawaguchi T: Efficacy and safety of nilotinib therapy in patients with newly diagnosed chronic myeloid leukemia in the chronic phase. Med Oncol, 2018; 35: 38 .

5) Takei H, Edahiro $Y$, Mano S, Masubuchi N, Mizukami Y, Imai M, Morishita S, Misawa K, Ochiai T, Tsuneda S, Endo H, Nakamura S, Eto K, Ohsaka A, Araki M, Komatsu N: Skewed megakaryopoiesis in human induced pluripotent stem cell-derived haematopoietic progenitor cells harbouring calreticulin mutations. Br J Haematol, 2018; 181: 791-802.

6) Takaku T, Iriyama N, Mitsumori $T$, Sato E, Gotoh A, Kirito K, Noguchi M, Koike M, Sakamoto J, Oba K, Komatsu N: Clinical Efficacy and Safety of First-Line Dasatinib Therapy and the Relevance of Velocity of BCR-ABL1 Transcript Decline for Achievement of Molecular Responses in Newly Diagnosed Chronic-Phase Chronic Myeloid Leukemia: Report from the Juntendo Yamanashi Cooperative Study Group. Oncology, 2018; 94: 85-91.

7) Shingai N, Harada Y, Iizuka H, Ogata Y, Doki N, Ohashi K, Hagihara M, Komatsu N, Harada $\mathrm{H}$ : Impact of splicing factor mutations on clinical features in patients with myelodysplastic syndromes. Int J Hematol, 2018; 108: 598-606.

8) Sato E, Iriyama N, Tokuhira M, Takaku T, Ishikawa M, Nakazato T, Sugimoto KJ, Fujita H, Fujioka I, Asou N, Komatsu N, Kizaki M, Hatta Y, Kawaguchi T: Introduction of second-generation tyrosine kinase inhibitors may reduce the prognostic impact of highrisk patients, according to the European treatment and outcome study (EUTOS) score. Leuk Lymphoma, 2018; 59: 1105-1112.

9) Ishibashi M, Soeda S, Sasaki M, Handa H, Imai Y, Tanaka N, Tanosaki S, Ito S, Odajima T, Sugimori H, Asayama T, Sunakawa M, Kaito Y, Kinoshita R, Kuribayashi Y, Onodera A, Moriya K, Tanaka J, Tsukune Y, Komatsu N, Inokuchi $\mathrm{K}$, Tamura $\mathrm{H}$ : Clinical impact of serum soluble SLAMF7 in multiple myeloma. Oncotarget, 2018; 9: 34784-34793.

10) Iriyama N, Sugimoto K, Sato E, Takaku T, Tokuhira M, Nakazato T, Ishikawa M, Fujita H, Fujioka I, Kimura Y, Asou N, Kizaki M, Komatsu N, Hatta Y, Kawaguchi T: Comparison of the clinical outcomes of nilotinib and dasatinib therapies in newly diagnosed patients in the chronic phase of chronic myeloid leukemia: a retrospective analysis. Med Oncol, 2018; 35: 142.

11) Inokuchi $K$, Nakayama $K$, Tauchi $T$, Takaku $\mathrm{T}$, Yokose N, Yamaguchi H, Kumagai T, Komatsu N, Ohyashiki K: Therapeutic effects of tyrosine kinase inhibitors and subtypes of BCR-ABL1 transcripts in Japanese chronic myeloid leukemia patients with three-way chromosomal translocations. Leuk Res, 2018; 65: 74-79.

12) Oritani K, Ohishi K, Okamoto S, Kirito K, Komatsu N, Tauchi T, Handa H, Saito S, Takenaka K, Shimoda K, Okada H, Amagasaki T, Wakase S, Shimozuma K, Akashi K: Effect of ruxolitinib therapy on the qualityof-life of Japanese patients with myelofibrosis. Curr Med Res Opin, 2018; 34: 531-537.

13) Ochiai T, Yasuda H, Araki M, Misawa K, Morishita S, Nudejima M, Hironaka Y, Shirane S, Edahiro Y, Gotoh A, Ohsaka A, Komatsu N: The 2014 BCSH criteria and the 2016 WHO criteria for essential thrombocythemia: A comparison in a large-scale cohort. Eur J Haematol, 2018; 100: 544-549.

14) Nitta H, Gotoh A, Tanaka M, Sekiguchi $Y$, Ota Y, Noguchi M, Komatsu N: Pleural effusion at diagnosis predicts extremely poor outcomes in patients with diffuse large B-cell lymphoma harbouring MYC rearrangement. Br J Haematol, Epub 2018 Jul 5.

15) Nakazato T, Iriyama N, Tokuhira M, Ishikawa M, Sato E, Takaku T, Sugimoto KJ, 
Fujita H, Fujioka I, Kimura Y, Aisa Y, Iwanaga E, Asou N, Kizaki M, Hatta Y, Komatsu $\mathrm{N}$, Kawaguchi $\mathrm{T}$ : Incidence and outcome of second malignancies in patients with chronic myeloid leukemia during treatment with tyrosine kinase inhibitors. Med Oncol, 2018; 35: 99.

16) Nakamura A, Misawa S, Chonan M, Kawakami T, Horii T, Komatsu N, Ohsaka A: Efficacy of PCR-based open reading frame typing assay for outbreak investigation of metallo- $\beta$-lactamase-producing Pseudomonas aeruginosa in hematology unit. J Infect Chemother, 2018; 24: 1020-1023.

17) Mori $T$, Watanabe $N$, Kitahara H, Iwao N, Koike M, Komatsu N: Acquired Factor VIII Inhibitor in a Patient of Rheumatoid Arthritis on Tumor Necrosis Factor Inhibitor Therapy. Indian J Hematol Blood Transfus, Epub 2018 Oct 16.

18) Misawa K, Yasuda H, Araki M, Ochiai T, Morishita S, Shirane S, Edahiro Y, Gotoh A, Ohsaka A, Komatsu N: Mutational subtypes of JAK2 and CALR correlate with different clinical features in Japanese patients with myeloproliferative neoplasms. Int J Hematol, 2018; 107: 673-680.

19) Kirito $K$, Okamoto $S$, Ohishi $K$, Tauchi $T$, Handa H, Saito S, Takenaka K, Shimoda K, Oritani K, Akashi K, Okada H, Amagasaki T, Suzuki K, Yonezu T, Komatsu N: Evaluation of the dose and efficacy of ruxolitinib in Japanese patients with myelofibrosis. Int J Hematol, 2018; 107: 92-97.

20) Ishibashi M, Soeda S, Sasaki M, Handa H, Imai Y, Tanaka N, Tanosaki S, Ito S, Odajima T, Sugimori H, Asayama T, Sunakawa M, Kaito Y, Kinoshita R, Kuribayashi Y, Onodera A, Moriya K, Tanaka J, Tsukune Y, Komatsu N, Inokuchi K, Tamura H: Clinical impact of serum soluble SLAMF7 in multiple myeloma. Oncotarget, 2018; 9: 34784-34793.

21) Fujioka I, Takaku T, Iriyama N, Tokuhira M, Kimura Y, Sato E, Ishikawa M, Nakazato T, Sugimoto KJ, Fujita H, Asou N, Kizaki M, Hatta Y, Komatsu N, Kawaguchi T: Features of vascular adverse events in Japanese patients with chronic myeloid leukemia treated with tyrosine kinase inhibitors: a retrospective study of the CML Cooperative Study Group database. Ann Hematol, 2018; 97: 2081-2088.

22) Asakura K, Azechi T, Sasano H, Matsui H, Hanaki H, Miyazaki M, Takata T, Sekine M, Takaku T, Ochiai T, Komatsu N, Shibayama K, Katayama Y, Yahara K: Rapid and easy detection of low-level resistance to vancomycin in methicillin-resistant Staphylococcus aureus by matrix-assisted laser desorption ionization time-of-flight mass spectrometry. PLoS One, 2018; 13: e0194212.

23) Sakamoto K, Katayama R, Asaka R, Sakata S, Baba S, Nakasone H, Koike S, Tsuyama N, Dobashi A, Sasaki M, Ichinohasama R, Takakuwa E, Yamazaki R, Takizawa J, Maeda T, Narita M, Izutsu K, Kanda Y, Ohshima K, Takeuchi K: Recurrent 8q24 rearrangement in blastic plasmacytoid dendritic cell neoplasm: association with immunoblastoid cytomorphology, MYC expression, and drug response. Leukemia, 2018; 32: 2590-2603.

24) Noguchi S, Nakaseko C, Nishiwaki K, Ogasawara H, Ohishi K, Tokuhira M, Noguchi M, Kimura H, Handa H, Mitani K, Miura M, Wakita H, Takahashi N; STAT study group: Switching to nilotinib is associated with deeper molecular responses in chronic myeloid leukemia chronic phase with major molecular responses to imatinib: STAT1 trial in Japan. Int J Hematol, 2018; 108: 176-183.

〈Reviews〉

1) Edahiro Y, Ando J, Suzuki T, Fukumura Y, Masuda A, Sakayori S, Takeda J, Maruyama Y, Makino S, Itakura A, Komatsu N: Multiple Placental Infarcts in a Pregnant Woman with Essential Thrombocythemia. Intern Med, 2018; 2018; 57: 3647-3650.

2) Araki M, Komatsu N: Mutant molecular chaperone activates cytokine receptor as a homomultimer. Oncotarget, 2018; 9: 3520135202 .

\section{Department of Pediatrics and Adolescent Medicine}

〈Original Articles〉

1) Guarino A, Lo Vecchio A, Dias JA, Berkley JA, Boey C, Bruzzese D, Cohen MB, Cruchet S, Liguoro I, Salazar-Lindo E, Sandhu B, Sherman PM, Shimizu T: Universal 
recommendations for the management of acute diarrhea in nonmalnourished children. J Pediatr Gastroenterol Nutr, 2018; 67: 586593.

2) Maehara A, Kaitani A, Izawa K, Shiba E, Nagamine M, Takamori A, Isobe M, Uchida S, Uchida K, Ando T, Keiko M, Nakano N, Voehringer D, Roers A, Shimizu T, Ogawa H, Okumura K, Kitamura T, Kitaura J: Role of the ceramide-CD300f interaction in gramnegative bacterial skin infections. J Invest Dermatol, 2018; 138: 1221-1224.

3) Masamune A, Kikuta K, Hamada S, Nakano E, Kume K, Inui A, Shimizu T, Takeyama Y, Nio M, Shimosegawa T: Nationwide survey of hereditary pancreatitis in Japan. J Gastroenterol, 2018; 53: 152-160.

4) Okumura A, Ida S, Mori M, Shimizu T; On behalf for Committee on Pediatric Nutrition of The Japan Pediatric Society: Attitudes of pediatricians toward Children's consumption of ionic beverages. BMC Pediatr, 2018; 18: 176.

5) Okumura A, Ida S, Mori M, Shimizu T; Committee on Pediatric Nutrition of the Child Health Consortium of Japan: Vitamin B1 Deficiency Related to Excessive Soft Drink Consumption in Japan. J Pediatr Gastroenterol Nut, 2018; 66: 838-842.

6) Imoto $N$, Obinata K, Nakazawa T, Sasaki S: Validation of PCR-Based testing for surveillance of drug resistant Acinetobacter baumannii (ISAbal/blaOXA-51-Like) in pediatric ward. Juntendo Medical Journal, 2018; 64: 461-467.

7) Baba S, Kobayashi A, Yokoyama H, Moriyama K, Kashimada A, Oyama J, Owada A, Oyama S, Morio T, Takagi M: Slowly progressive leukodystrophy in an adolescent male with phosphoglycerate kinase deficiency. Brain Dev, 2018; 40: 150-154.

8) Ohtomo Y: Pathophysiology and treatment of enuresis: Focus on sleep. Pediatr Int, 2018; 60: 997.

9) Kantake M, Ohkawa N, Iwasaki T, Ikeda N, Awaji A, Saito N, Shoji H, Shimizu T: Postnatal relative adrenal insufficiency results in methylation of the glucocorticoid receptor gene in preterm infants: a retrospective cohort study. Clin Epigenetics, 2018; 10: 66.

10) Kantake M: The Origin of CD45+CD71Cells Enriched by MACS Technology. Biomed J Sci \& Tech Res, 2018; 8: 6484-6486.

11) Kantake M: Simple, rapid and effective separation of nuclear red blood cells from peripheral blood of pregnant women: A preliminary study. Biomed J Sci \& Tech Res, 2018; 3: 33000-33003.

12) Kamei H, Yoneyama Y, Hakuno F, Sawada R, Shimizu T, Duan C, Takahashi SI: Catch-up growth in zebrafish embryo requires neural crest cells sustained by Irs1 signaling. Endocrinology, 2018; 159: 1547-1560.

13) Stephanie $M$, Irie $R$, Sasaki $K$, Hirata $Y$, Narumoto S, Fukuda A, Sakamoto S, Arai K, Yoshioka T, Kasahara M: Histological changes of the intestinal mucosa in complications following a living donor liver transplantation for progressive familial intrahepatic cholestasis type 1. Pathol Int, 2018; 68: 536-537.

14) Kubota T, Nakayama H, Kitaoka T, Nakamura Y, Fukumoto S, Fujiwara I, Hasegawa Y, Ihara K, Kitanaka S, Koyama S, Kusuda S, Mizuno H, Nagasaki K, Oba K, Sakamoto Y, Takubo N, Shimizu T, Tanahashi Y, Hasegawa K, Tsukahara H, Yorifuji T, Michigami $\mathrm{T}$, Ozono K: Incidence rate and characteristics of symptomatic vitamin $\mathrm{D}$ deficiency in children: a nationwide survey in Japan. Endocr J, 2018; 65: 593-599.

15) Muto M, Matsufuji H, Taguchi T, Tomomasa T, Nio M, Tamai H, Tamura M, Sago H, Toki A, Nosaka S, Kuroda T, Yoshida M, Nakajima A, Kobayashi H, Sou H, Masumoto K, Watanabe Y, Kanamori Y, Hamada Y, Yamataka A, Shimojima N, Kubota A, Ushijima K, Haruma K, Fukudo S, Araki Y, Kudo T, Obata S, Sumita W, Watanabe T, Fukahori S, Fujii Y, Yamada Y, Jimbo K, Kawai F, Fukuoka T, Onuma S, Morizane T, Ieiri S, Esumi G, Jimbo $\mathrm{T}$, Yamasaki $\mathrm{T}$ : Japanese clinical practice guidelines for allied disorders of Hirschsprung's disease, 2017. Pediatr Int, 2018; 60: 400-410.

16) Shoji H, Ikeda N, Kitamura T, Suganuma $H$, Ohba M, Okuno T, Yokomizo T, Shimizu T: Urinary prostaglandin D2 metabolite excretion during the first six months of life was 
significantly lower in breast-fed than formula-fed infants. Acta Paediatr, 2018; 107: 95-100.

17) Shoji H, Taka H, Kaga N, Ikeda N, Hisata K, Miura Y, Shimizu T: Choline-related metabolites influenced by feeding patterns in preterm and term infants. J Matern Fetal Neonatal Med, Epub 2018 Jul 22.

18) Fujinaga S, Nishino T: Favorable renal outcome of Japanese children with severe IgA nephropathy with nephrotic syndrome. Indian Pediatr, 2018; 55: 605-607.

19) Fujinaga $S$, Nishino $T$ : Is cytokine-release syndrome the cause of rituximab treatmentrelated infusion reactions in children with nephrotic syndrome? Impact of anti-rituximab antibodies. Pediatr Nephrol, 2018; 33: 1097-1098.

20) Fujinaga S, Sakuraya K: Should mycophenolate mofetil be administered prior to cyclosporine $\mathrm{A}$ as a steroid-sparing agent to children with steroid-dependent nephrotic syndrome? Pediatr Nephrol, 2018; 33: 23892390.

21) Fujinaga S, Sakuraya K: Initial prednisolone dosing for the first relapse of steroid-sensitive nephrotic syndrome in Japanese children. Pediatr Nephrol, 2018; 33: 2205-2206.

22) Horinouchi T, Nozu K, Yamamura T, Minamikawa S, Omori T, Nakanishi K, Fujimura J, Ashida A, Kitamura M, Kawano M, Shimabukuro W, Kitabayashi C, Imafuku A, Tamagaki K, Kamei K, Okamoto K, Fujinaga S, Oka M, Igarashi T, Miyazono A, Sawanobori E, Fujimaru R, Nakanishi K, Shima Y, Matsuo M, Ye MJ, Nozu Y, Morisada N, Kaito H, Iijima K: Detection of splicing abnormalities and genotype-phenotype correlation in X-linked alport syndrome. J Am Soc Nephrol, 2018; 29: 22442254.

23) Yamada A, Fujinaga S, Sakuraya K, Satoshi A, Hirano D: Initial treatment with pulse methylprednisolone followed by short-term prednisolone and tonsillectomy for childhood IgA nephropathy. Clin Exp Nephrol, 2018; 22: 1143-1149.

24) Shima H, Hayashi M, Tachibana T, Oshiro M, Amano N, Ishii T, Haruna H, Igarashi M, Kon M, Fukuzawa R, Tanaka Y, Fukami M,
Hasegawa T, Narumi S: MIRAGE syndrome is a rare cause of $46, \mathrm{XY}$ DSD born SGA without adrenal insufficiency. PLoS One, 2018; 13: e0206184.

25) Suzuki M, Minowa K, Tajiri H: Interferonbased Simeprevir Therapy for Pediatric Patients with Chronic Hepatitis C Viral Infection. Ann Hepatol, 2018; 17: 756-758.

26) Mizuochi T, Takano T, Yanagi T, Ushijima K, Suzuki M, Miyoshi Y, Ito Y, Inui A, Tajiri H: Epidemiologic features of 348 children with hepatitis C virus infection over a 30 -year period: a nationwide survey in Japan. J Gastroenterol, 2018; 53: 419-426.

27) Okumura A, Ida S, Ito S, Oguni T, Suzuki M, Mori M, Shimizu T: Parental awareness of young children's pattern of ionic beverage consumption. Pediatr Int, 2018; 60: 969-973.

28) Sakamoto Y, Ishijima M, Kinoshita M, Liu L, Suzuki M, Kim SG, Kamata K, Tokita A, Kaneko H, Shimizu T, Kaneko K, Nozawa M: Association between leg bowing and serum alkaline phosphatase level regardless of the presence of a radiographic growth plate abnormality in pediatric patients with genu varum. J Bone Miner Metab, 2018; 36: 447453.

29) Wakano Y, Sugiura T, Endo T, Ito K, Suzuki M, Tajiri H, Tanaka Y, Saitoh S: Antiviral therapy for hepatitis B virus during second pregnancies. J Obstet Gynaecol Res, 2018; 44: 566-569.

30) Suganuma H, Ikeda N, Ohkawa N, Shoji H, Shimizu T: Influence of i.v. lipid emulsion on lipoprotein subclass in preterm infants. Pediatr Int, 2018; 60: 839-843.

31) Murakami K, Yamamoto Y, Fukunaga H, Matsushita M, Hirai C, Makino S, Shimizu T, Itakura A, Takeda S: Predictive markers and prenatal management of isolated fetal complete atrioventricular block: A retrospective review at a single institution. J Obstet Gynaecol Res, 2018; 44: 228-233.

32) Ikuse $T$, Ohtsuka Y, Obayashi N, Jimbo K, Aoyagi Y, Kudo T, Asaoka D, Hojo M, Nagahara A, Watanabe S, Blanchard TG, Czinn SJ, Shimizu T: Host response genes associated with nodular gastritis in Helicobacter pylori infection. Pediatr Int, 2018; 60: 
446-454.

33) Murano Y, Shoji H, Hara T, Ikeda N, Endo A, Nishizaki N, Shimizu T: Long-term renal tubular damage in intrauterine growthrestricted rats. Pediatr Int, 2018; 60: 565-568.

*34) Igarashi A, Sakuma H, Hayashi M, Noto D, Miyake S, Okumura A, Shimizu T: Cytokineinduced differentiation of hematopoietic cells into microglia-like cells in vitro. Clin Exp Neuroimmunol, 2018; 9: 139-149.

35) Kurahashi H, Azuma Y, Masuda A, Okuno T, Nakahara E, Imamura T, Saitoh M, Mizuguchi M, Shimizu T, Ohno K, Okumura A: MYRF is associated with encephalopathy with reversible myelin vacuolization. Ann Neurol, 2018; 83: 98-106.

*36) Mitomo S, Hosozawa M, Yoshikawa N, Tanaka K, Shimizu T: Correlation between the Bayley scales of infant and toddler development, third edition and subsequent cognitive function at age 6 years in very-lowbirthweight children, 2018; 64: 454-460.

37) Kamei H, Yoneyama Y, Hakuno F, Sawada R, Shimizu T, Duan C, Takahashi SI: Catch-up growth in zebrafish embryo requires neural crest cells sustained by Irs1 signaling. Endocrinology, 2018; 159: 1547-1560.

*38) Sakaguchi K, Koyanagi A, Kamachi F, Harauma A, Chiba A, Hisata K, Moriguchi T, Shimizu T, Miyake S: Breastfeeding regulates development of immune system through TGF- $\beta$ in mice pups. Pediatr Int, 2018; 60: 224-231.

*39) Shima T, Sakuma H, Suzuki T, Kohyama K, Matsuoka T, Hayashi M, Okumura A, Shimizu T: Effects of antiepileptic drugs on microglial properties. Epilepsy \& Seizure, 2018; 10: 22-32.

40) Nakano S, Suzuki M, Minowa K, Hirai S, Takubo N, Sakamoto Y, Ishijima M, Hoshino E, Tokita A, Shimizu T: Current vitamin D status in healthy Japanese infants and young children. J Nutr Sci Vitaminol (Tokyo), 2018; 64: 99-105.

41) Nakano S, Suzuki M, Minowa K, Hirai S, Takubo N, Sakamoto Y, Ishijima M, Hoshino E, Tokita A, Shimizu T: Vitamin D deficiency in healthy Japanese infants and young children. J Nutr Sci Vitaminol (Tokyo), 2018;
64: 99-105.

42) Hayashi H, Naoi S, Togawa T, Hirose $Y$, Kondou H, Hasegawa Y, Abukawa D, Sasaki M, Muroya K, Watanabe S, Nakano S, Minowa K, Inui A, Fukuda A, Kasahara M, Nagasaka H, Bessho K, Suzuki M, Kusuhara H: Assessment of ATP8B1 deficiency in pediatric patients with cholestasis using peripheral blood monocyte-derived macrophages. EBioMedicine, 2018; 7: 187-199.

*43) Yazaki K, Takahashi K, Shigemitsu S, Yamada M, Iso T, Kobayashi M, Akimoto K, Tamaichi H, Fujimura J, Saito M, Nii M, Shimizu T: In-depth insight into the mechanisms of cardiac dysfunction in patients with childhood cancer after anthracycline treatment using layer-specific strain analysis. Circ J, 2018; 82: 715-723.

44) Kaitani A, Izawa K, Maehara A, Isobe M, Takamori A, Matsukawa T, Takahashi M, Yamanishi Y, Oki T, Yamada H, Nagamine M, Uchida S, Uchida K, Ando T, Maeda K, Nakano N, Shimizu T, Takai T, Ogawa H, Okumura K, Kitamura T, Kitaura J: Leukocyte mono-immunoglobulin-like receptor 8 (LMIR8)/CLM-6 is an FcR $r$-coupled receptor selectively expressed in mouse tissue plasmacytoid dendritic cells. Sci Rep, 2018; 8: 8259.

45) Katoh-Fukui Y, Yatsuga S, Shima H, Hattori A, Nakamura A, Okamura K, Yanagi K, Iso M, Kaname T, Matsubara Y, Fukami M: An unclassified variant of CHD7 activates a cryptic splice site in a patient with CHARGE syndrome. Hum Genome Var, 2018; 5: 18006.

46) Okumura A, Maruyama K, Shibata M, Kurahashi H, Ishii A, Numoto S, Hirose S, Kawai T, Iso M, Kataoka S, Okuno Y, Muramatsu H, Kojima S: A patient with a GNAO1 mutation with decreased spontaneous movements, hypotonia, and dystonic features. Brain Dev, 2018; 40: 926-930.

47) Ogura K, Okumura K, Shimizu Y, Kirikae T, Miyoshi-Akiyama T: Pathogenicity Induced by Invasive Infection of Streptococcus dysgalactiae subsp. equisimilis in a Mouse Model of Diabetes. Front Microbiol, 2018; 9: 2128.

48) Mototani Y, Okamura T, Goto M, Shimizu Y, Yanobu-Takanashi R, Ito A, Kawamura N, 
Yagisawa Y, Umeki D, Nariyama M, Suita K, Ohnuki Y, Shiozawa K, Sahara Y, Kozasa T, Saeki Y, Okumura S: Role of G proteinregulated inducer of neurite outgrowth 3 (GRIN3) in $\beta$-arrestin 2 -akt signaling and dopaminergic behaviors. Pflugers Arch, 2018; 470: 937-947.

〈Reviews〉

1) Inage E, Furuta GT, Menard-Katcher $C$, Masterson JC: Eosinophilic esophagitis: pathophysiology and its clinical implications. Am J Physiol Gastrointest Liver Physiol, 2018; 315: G879-G886.

2) Dellon ES, Liacouras CA, Molina-Infante J, Furuta GT, Spergel JM, Zevit N, Spechler SJ, Attwood SE, Straumann A, Aceves SS, Alexander JA, Atkins D, Arva NC, Blanchard C, Bonis PA, Book WM, Capocelli KE, Chehade M, Cheng E, Collins MH, Davis CM, Dias JA, Di Lorenzo C, Dohil R, Dupont C, Falk GW, Ferreira CT, Fox A, Gonsalves NP, Gupta SK, Katzka DA, Kinoshita Y, MenardKatcher C, Kodroff E, Metz DC, Miehlke S, Muir AB, Mukkada VA, Murch S, Nurko S, Ohtsuka Y, Orel R, Papadopoulou A, Peterson KA, Philpott H, Putnam PE, Richter JE, Rosen R, Rothenberg ME, Schoepfer A, Scott MM, Shah N, Sheikh J, Souza RF, Strobel MJ, Talley NJ, Vaezi MF, Vandenplas Y, Vieira MC, Walker MM, Wechsler JB, Wershil BK, Wen T, Yang GY, Hirano I, Bredenoord AJ: Updated international consensus diagnostic criteria for eosinophilic esophagitis: Proceedings of the AGREE conference. Gastroenterology, 2018; 155: 1022-1033.e10.

3) Miller J, Tonkin E, Damarell RA, McPhee AJ, Suganuma M, Suganuma H, Middleton PF, Makrides M, Collins CT: A systematic review and meta-analysis of human milk feeding and morbidity in very low birth weight infants. Nutrients, 2018; 10: 707.

4) Ikuse T, Kudo T, Arai K, Fujii $Y$, Ida S, Ishii T, Mushiake S, Nagata K, Tamai H, Toki A, Tomomasa T, Ushijima K, Yanagi T, Yonekura T, Taguchi T, Shimizu T: Shwachmandiamond syndrome: A nationwide survey and a systematic review in Japan. Pediatr Int, 2018; 60: 719-726.

\section{Department of Anesthesiology}

〈Original Articles〉

1) Inoue $R$, Sumikura $H$, Kumagai $A$, Kato $N$, Makino S, Itakura A: Successful management of obstetric disseminated intaravascular coagulation using a poratblefibrinogen measuring device. J Obstet Gynaecol Res, 2018; 44: 788-791.

2) Tsutsui Y, Mizuno J, Sunada K: Does the aroma of a patient's preferred dental topical anaesthetic affect anxiety, fear, and autonomic nervous system activity prior to dental local anaesthesia? A randomized trial. Flavour and Fragrance Journal, 2018; 33: 405-410.

3) Inomata T, Mizuno J, Iwagami M, Kawasaki S, Shimada A, Inada E, Shian T, Amano A: The impact of Joint Commission International accreditation on time periods in the operating room: A retrospective observational study. PLoS One, 2018; 13: e0204301.

4) Aoki Y, Nishizawa D, Yoshida K, Hasegawa J, Kasai S, Kaori Takahashi K, Koukita Y, Ichinohe T, Hayashida M, Fukuda K, Ikeda K: Association between the rs7583431 single nucleotide polymorphism close to the activating transcription factor 2 gene and the analgesic effect of fentanyl in the cold pain test. Neuropsychopharmacol Rep, 2018; 38: 86-91.

* 5) Yamamoto M, Hayashida M, KakemizuWatanabe M, Ando N, Mukaida H, Kawagoe I, Yusuke S, Inada E: B-Type Natriuretic Peptide and Hemoglobin are Two Major Factors Significantly Associated With Baseline Cerebral Oxygen Saturation Measured Using the INVOS Oximeter in Patients Undergoing Off-Pump Coronary Artery Bypass Graft Surgery. J Cardiothorac Vasc Anesth, 2018; 32: 187-196.

6) Okada H, Kuroda Y, Amano K, Kikuchi T, Matsuoka S, Ogishima D: Recurrent spontaneous cervical epidural hematoma in a parturient 11 hours after vaginal delivery without labor epidural analgesia. Int J Obstet Anesth, 2018; 35: 108-109.

7) Sakuraba S, Omae T, Kawagoe I, Koh K, Inada $\mathrm{E}$ : Respiratory failure caused by impending tension pneumothorax after extrapleural pneumonectomy: a case report. 
JA Clin Rep, 2018; 4: 45.

8) Kawagoe I, Hayashida M, Satoh D, Suzuki K Inada E: Ventilation failure after lateral jackknife positioning for robot-assisted lung cancer surgery in a patient after lingula-sparing left upper lobectomy. JA Clin Rep, 2018; 4: 51.

9) Fukui M, Suzuki M, Kawagoe I, Hirayama S, Tachi R, Koike Y, Takamochi K, Oh S, Suzuki $\mathrm{K}$ : Case report of cardiac herniation after sleeve pneumonectomy with superior vena cava reconstruction. Gen Thorac Cardiovasc Surg, Epub 2018 Sep 8.

10) Sugiyama $Y$, Iida $H$, Amaya $F$, Matsuo $K$, Matsuoka Y, Kojima K, Matsuno F, Hamaguchi T, Iseki M, Yamaguchi K, Takahashi Y, Hara A, Sugasawa Y, Kawamata M, Tanaka S, Inagaki Y, Otsuki A, Yamazaki M, Ito H: Prevalence of chronic postsurgical pain after thoracotomy and total knee arthroplasty: a retrospective multicenter study in Japan (Japanese Study Group of Subacute Postoperative Pain). J Anesth, 2018; 32: 434-438.

11) Ishikawa $R$, Iseki $M$, Koga $R$, Inada $E$ : Investigation of the Correlation between Postherpetic Itch and Neuropathic Pain over Time. Pain Res Manag, 2018; 2018: 9305126.

12) Satoh D, Toda N, Yamamoto I: Effects of intraoperative nutrients administration on energy expenditure during general anesthesia. Nutrition, 2018; 45: 37-40.

13) Mitaka C, Odoh M, Satoh D, Hashiguchi $T$, Inada E: High-flow oxygen via tracheostomy facilitates weaning from prolonged mechanical ventilation in patients with restrictive pulmonary dysfunction: two case reports. J Med Case Rep, 2018; 12: 292.

14) Saito T, Sakai $Y$, Saito A, Sumikura H, Inada E: The usability of desflurane for laparoscopic adrenalectomy in pregnancy with Cushing's syndrome: a case report. M E J Anesth, 2018; 25: 113-116.

15) Inomata $T$, Mizuno J, Iwagami $M$, Kawasaki S, Shimada A, Inada E, Shiang T, Amano A: The impact of Joint Commission International accreditation on time periods in the operating room: A retrospective observational study. PLoS One, 2018; 13: e0204301.

$\langle$ Reviews〉

1) Sumikura H: Do fetuses need vasopressors just before their birth? J Anesth, 2018; 32: 481-482.

2) Omae $T$, Inada $E$ : New-onset atrial fibrillation: an update. J Anesth, 2018; 32: 414-424. 〈Books〉

1) Okada H: Comment on "The Evolving Delemma of Factor XI in Pregnancy. Suggestions for Management." Obstetric Anesthesia Digest: December 2018 Volume 38-Issue 4-p207-209.

2) Okada H: Anesthesiology Japanese podcast December 2018 Japanese Translation. http: //anesthesiology.asahq.org/ss/Japanese Podcast.aspx

3) Kishii J, Satoh D, MayumiT, Izumi K, Inada E: Effect of Intraoperative Nutrients Administration on Metabolism Under General Anesthesia. http://asaabstracts.com/strands/asaa bstracts/abstract.htm? year $=2018 \&$ index $=17$ \&absnum $=3814$

\section{Department of Clinical Laboratory Medicine}

$\langle$ Original Articles〉

1) Tabe $Y$, Saitoh K, Yang H, Sekihara K, Yamatani K, Ruvolo V, Taka H, Kaga N, Kikkawa M, Arai H, Miida T, Andreeff M, Spagnuolo PA, Konopleva M: Inhibition of FAO in AML co-cultured with BM adipocytes: mechanisms of survival and chemosensitization to cytarabine. Sci Rep, 2018; 8: 16837.

* 2) Isshiki M, Hirayama S, Ueno T, Ito M, Furuta A, Yano K, Yamatani K, Sugihara M, Idei M, Miida T: Apolipoproteins C-II and C-III as nutritional markers unaffected by inflammation. Clin Chim Acta, 2018; 481: 225-230.

3) Sekihara K, Saitoh K, Yang H, Kawashima H, Kazuno S, Kikkawa M, Arai H, Miida T, Hayashi N, Sasai K, Tabe Y: Low-dose ionizing radiation exposure represses the cell cycle and protein synthesis pathways in in vitro human primary keratinocytes and U937 cell lines. PLoS One, 2018; 13: e0199117.

* 4) Yamashita Y, Nakada S, Yoshihara T, Nara T, Furuya N, Miida T, Hattori N, Arikawa-Hirasawa E: Perlecan, a heparan sulfate proteoglycan, regulates systemic metabolism with dynamic changes in adipose tissue and skeletal muscle. Sci Rep, 2018; 8: 7766. 
5) Hirayama S, Nagasaka H, Honda A, Komatsu H, Kodama T, Inui A, Morioka I, Kaji S, Ueno $\mathrm{T}$, Ihara K, Yagi M, Kizaki Z, Bessho K, Kondou H, Yorifuji T, Tsukahara H, Iijima K, Miida T: Cholesterol metabolism is enhanced in the liver and brain of children with citrin deficiency. J Clin Endocrinol Metab, 2018; 103: 2488-2497.

6) Nagasaka H, Hirano KI, Yorifuji T, Komatsu H, Takatani T, Morioka I, Hirayama S, Miida $\mathrm{T}$ : Treatment with medium chain fatty acids milk of CD36-deficient preschool children. Nutrition, 2018; 50: 45-48.

7) Nagasaka H, Morioka I, Takuwa M, Nakacho M, Yoshida M, Ishida A, Hirayama S, Miida T, Tsukahara H, Yorifuji T, Iijima K: Blood asymmetric dimethylarginine and nitrite/ nitrate concentrations in short-stature children born small for gestational age with and without growth hormone therapy. J Int Med Res, 2018; 46: 761-772.

8) Fujisawa S, Ueda Y, Usuki K, Kobayashi H, Kondo E, Doki N, Nakao T, Kanda Y, Kosugi N, Kosugi H, Kumagai T, Harada H, Shikami M, Maeda Y, Sakura T, Inokuchi K, Saito A, Nawa Y, Ogasawara M, Nishida J, Kondo T, Yoshida C, Kuroda H, Tabe Y, Maeda Y, Imajo K, Kojima K, Morita S, Komukai S, Kawaguchi A, Sakamoto J, Kimura S: Feasibility of the imatinib stop study in the Japanese clinical setting: delightedly overcome CML expert stop TKI trial (DOMEST Trial). Int J Clin Oncol, Epub 2018 Nov 12.

* 9) Tsuchiya K, Tabe Y, Ai T, Ohkawa T, Usui K, Yuri M, Misawa S, Morishita S, Takaku T, Kakimoto A, Yang H, Matsushita H, Hanami T, Yamanaka Y, Okuzawa A, Horii T, Hayashizaki Y, Ohsaka A: Eprobe mediated RT-qPCR for the detection of leukemia-associated fusion genes. PLoS One, 2018; 13: e0202429.

10) Takemura H, Ai T, Kimura K, Nagasaka K, Takahashi T, Tsuchiya K, Yang H, Konishi A, Uchihashi K, Horii T, Tabe Y, Ohsaka A: Evaluation of cell count and classification capabilities in body fluids using a fully automated Sysmex XN equipped with highsensitive Analysis (hsA) mode and DI-60 hematology analyzer system. PLoS One, 2018;
13: e0195923.

11) Molina JR, Sun Y, Protopopova M, Gera S, Bandi M, Bristow C, McAfoos T, Morlacchi P, Agip AA, Al-Atrash A, Asara J, Bardenhagen J, Carrillo CC, Carroll C, Chang E, Ciurea S, Cross JB, Czako B, Deem A, Daver N, de Groot JF, Dong JW, Feng N, Gao G, Gay J, Do MG, Greer J, Han J, Henry VK, Hirst J, Huang S, Jiang Y, Kang Z, Konoplev S, Liu G, Lodi A, Lofton T, Ma H, Matre P, Mullinax P, Peoples M, Petrocchi A, Rodriguez-Canale J, Serreli R, Shi T, Smith M, Tabe Y, Theroff J, Tiziani S, Xu Q, Zhang Q, Muller F, DePinho RA, Toniatti C, Heffernan TP, Draetta GF, Konopleva M, Jones P, Di Francesco ME, Marszalek JR: Oxidative phosphorylation inhibitor exploits cancer vulnerability. Nat Med, 2018; 24: 1036-1046.

12) Zhang Q, Shi C, Han L, Jain N, Roberts KG, Ma H, Cai T, Cavazos A, Tabe Y, Jacamo RO, Mu H, Zhao Y, Wang J, Wu SC, Cao F, Zeng Z, Zhou J, Mi Y, Jabbour EJ, Levine R, Tasian SK, Mullighan CG, Weinstock DM, Fruman DA, Konopleva M: Inhibition of mTORC1/C2 signaling improves anti-leukemia efficacy of JAK/STAT blockade in CRLF2 rearranged and/or JAK driven Philadelphia chromosomelike acute B-cell lymphoblastic leukemia. Oncotarget, 2018; 9: 8027-8041.

13) Ai $T$, Tabe $Y$, Takemura H, Kimura K, Takahashi T, Yang H, Tsuchiya K, Konishi A, Uchihashi K, Horii T, Ohsaka A: Novel flowcytometry-based approach of malignant cell detection in body fluids using an automated hematology analyzer. PLoS One, 2018; 13: e0190886.

14) Shishido $Y$, Tomoike F, Kuwata K, Fujikawa H, Sekido Y, Murakami-Tonami Y, Kameda T, Abe N, Kimura Y, Shuto S, Abe H: A Covalent Inhibitor for Glutathione S-Transferase Pi (GSTP 1-1) in Human Cells. ChemBioChem, Epub 2019 Feb 15.

15) Okubo M, Nishida E, Watanabe A, Nishizaki N, Obinata K, Azuma F, Matsuhashi M, Watanabe-Okochi N, Tsuno NH, Miyake K, Yamaguchi M, Yoshida K: Marked thrombocytopenia in a neonate is associated with anti-HPA-5b, anti-HLA-A31, and antiHLA-B55 antibodies. Pediatr Blood Cancer, 
Epub 2018 Nov 28.

16) Murayama R, Kimura M, Yanasaki-Kato $Y$, Togo-Ohno M, Naruse T, Yamamoto T, Hayashi T, Ai T, Vatta M, Iizuka M, Saito M, Hiraoka Y, Kimura A, Kuroyanagi H: Phosphorylation of the RSRSP stretch is critical for splicing regiation by RNA-binding motif protein 20 (RBM20) through nuclear localizatopn. Sci Rep, 2018; 8: 8970.

17) Olaopa M, Spoonamore K, Bhakta D, Chen $Z$, Chen PS, Ai T, Vatta M: Lamin-A/C variants found in patients with cardiac conduction disease reduce sodium currents. Cardiogenetics 2018; 8: 7127.

18) Sato M, Ohkawa R, Low $H$, Nishimori $M$, Okubo S, Yoshimoto A, Yano K, Kameda T, Yatomi Y, Tozuka M: Serum amyloid A does not affect high-density lipoprotein cholesterol measurement by a homogeneous assay. Clin Biochem, Epub 2018 Oct 17.

19) Horiuchi Y, Ohkawa R, Lai S, Yamazaki A, Ikoma H, Yano K, Kameda T, Tozuka M: Characterization of the cholesterol efflux of apolipoprotein E-containing high-density lipoprotein in THP-1 cells. Biol Chem, Epub 2018 Sep 13.

20) Horiuchi Y, Lai S, Yamazaki A, Nakamura A, Ohkawa R, Yano K, Kameda T, Okubo S, Shimano S, Hagihara M, Tohda S, Tozuka M: Validation and application of a novel cholesterol efflux assay using immobilized liposomes as a substitute for cultured cells. Biosci Rep, 2018; 38: BSR20180144.

\section{Department of Aging Biology in Health and Disease}

〈Original Articles〉

* 1) Yamashita Y, Nakada S, Yoshihara T, Nara T, Furuya N, Miida T, Hattori N, ArikawaHirasawa E: Perlecan, a heparan sulfate proteoglycan, regulates systemic metabolism with dynamic changes in adipose tissue and skeletal muscle. Sci Rep, 2018; 8: 7766.

2) Ikeuchi T, de Vega S, Forcinito P, Doyle AD, Amaral J, Rodriguez IR, Arikawa-Hirasawa E, Yamada Y: Extracellular Protein Fibulin-7 and Its C-Terminal Fragment Have In Vivo Antiangiogenic Activity. Sci Rep, 2018; 8: 17654.

3) Irie R, Kamagata K, Kerever A, Ueda R,
Yokosawa S, Otake Y, Ochi H, Yoshizawa H, Hayashi A, Tagawa K, Okazawa H, Takahashi K, Sato K, Hori M, Arikawa-Hirasawa E, Aoki S: The Relationship between Neurite Density Measured with Confocal Microscopy in a Cleared Mouse Brain and Metrics Obtained from Diffusion Tensor and Diffusion Kurtosis Imaging. Magn Reson Med Sci, 2018; 17: $138-144$.

4) Nakazawa-Tanaka N, Fujiwara N, Miyahara K, Nakada S, Arikawa-Hirasawa E, Akazawa C, Urao M, Yamataka A: The effect of laminin-1 on enteric neural crest-derived cell migration in the Hirschsprung's disease mouse model. Pediatr Surg Int, 2018; 34: 143-147.

5) Fujiwara N, Nakazawa-Tanaka N, Miyahara $\mathrm{K}$, Arikawa-Hirasawa E, Akazawa C, Yamataka A: Altered expression of laminin alpha1 in aganglionic colon of endothelin receptor-B null mouse model of Hirschsprung's disease. Pediatr Surg Int, 2018; 34: 137-141.

\section{Department of Coloproctological Surgery}

〈Original Articles〉

1) Ohuchi M, Fukunaga M, Nagakari K, Azuma D, Kohama S, Nomoto J, Sakamoto K: Surgical technique and outcomes of transabdominal preperitoneal inguinal hernia repair after radical prostatectomy: dissection between the transversalis fascia and superficial layers of preperitoneal fascia. Hernia, Epub 2018 Jul 25.

2) Sakuyama N, Kojima M, Kawano S, Matsuda Y, Mino-Kenudson M, Ochiai A, Ito M: Area of residual tumor is a robust prognostic marker for patients with rectal cancer undergoing preoperative therapy. Cancer Sci, 2018; 109: 871-878.

3) Okazawa Y, Mizukoshi K, Koyama Y, Okubo S, Komiyama H, Kojima Y, Goto M, Habu S, Hino O, Sakamoto K, Orimo A: High-sensitivity Detection of Micrometastases Generated by GFP Lentivirus-transduced Organoids Cultured from a Patient-derived Colon Tumor. J Vis Exp, 2018; (136): 57374.

4) Munakata S, Sugimoto K, Honjo K, Kawai M, Kawano S, Kamiyama H, Ouchi M, Takahashi M, Tomiki Y, Sakamoto K: Neutrophil-Lymphocyte Ratio as a Prognostic Factor in 
Incurable Stage IV Colorectal Cancer. Open Journal of Gastroenterology, 2018; 8: 12.

5) Munakata S, Sakamoto K, Honjo K, Kawai M, Sugimoto K, Ouchi M, Takahashi M, Kojima Y, Nagakari K, Tomiki Y: Impact of Chylous Ascites on Colon Cancer in Laparoscopic Sugery. Open J Gastroenterol, 2018; 8: 269274.

6) Ro H, Munakata S, Ueyama T, Komiyama H, Takahashi M, Kojima Y, Tomiki Y, Sakamoto K: Pharmacological Targeting of Neutrophil Serine Proteases Prevents Lethality in Dextran Sulfate Sodium (DSS)-Induced Colitis in Mice. J Gastrointest Dig Syst, 2018; 8: 55.

7) Munakata S, Murai Y, Koizumi A, Kato H, Yamamoto R, Ueda S, Tokuda S, Sakuraba S, Kushida T, Orita H, Sakurada M, Maekawa H, Sato K: Mixed Neuroendocrine Carcinoma and Squamous Cell Carcinoma of the Colon: Case Report and Literature Review. Case Rep Gastroenterol, 2018; 12: 240-246.

8) Munakata S, Murai Y, Koizumi A, Kato H, Yamamoto R, Ueda S, Tokuda S, Sakuraba S, Kushida T, Orita H, Sakurada M, Maekawa H, Sato K: Abdominoperineal Resection for Unexpected Distal Intramural Spreading of Rectal Cancer. Case Rep Gastroenterol, 2018; 12: 297-302.

9) Kato H, Munakata S, Sakamoto K, Sugimoto K, Yamamoto R, Ueda S, TokudaS, Sakuraba S, Kushida T, Orita H, Sakurada M, Maekawa H, Sato K: Impact of Left Colonic Artery Preservation on Anastomotic Leakage in Laparoscopic Sigmoid Resection and Anterior Resection for Sigmoid and Rectosigmoid Colon Cancer. J Gastrointest Cancer, Epub 2018 Jul 10.

10) Munakata S, Murai $Y$, Koizumi A, Kato H, Yamamoto R, Ueda S, Tokuda S, Sakuraba S, Kushida T, Orita H, Sakurada M, Maekawa H, Sato K: Long-term outcomes of colorectal cancer patients with and without malignant large-bowel obstruction. Colorectal Cancer, 2018.

11) Tomiki $Y$, Kawai M, Kawano S, Ishiyama $S$, Sugimoto K, Takahashi M, Kojima Y, Murakami T, Ritsuno H, Shibuya T, Sakamoto N, Sakamoto K: Endoscopic Submucosal Dissection Decreases Additional Colorectal Resec- tion for T1 Colorectal Cancer. Med Sci Monit, 2018; 24: 6910-6917.

12) Takahashi M, Niitsu H, Sakamoto K, Hinoi $T$, Hattori M, Goto M, Bando H, Hazama S, Maeda K, Okita K, Horie H, Watanabe M; Japan Society of Laparoscopic Colorectal Surgery: Survival benefit of lymph node dissection in surgery for colon cancer in elderly patients: A multicenter propensity score-matched study in Japan. Asian J Endosc Surg, 2018; 11: 346-354.

13) Honjo K, Kazumasa K, Ro H, Mizukoshi K, Kawai M, Ishiyama S, Takahashi M, Tomiki Y, Sakamoto K: Rectal neuroendocrine tumors (NETs) treated by ESD with myectomy - video vignette. Colorectal Dis, 2018; 20: $1055-1056$.

〈Reviews〉

1) Sugimoto K, Ito T, Orita H, Fujita S, Sakamoto K, Sato K, Brock MV: DNA Methylation Research - My Experience in Johns Hopkins University -. Juntendo Medical Journal, 2018; 64: $2-10$.

\section{Department of Hepato-Biliary-Pancreatic Surgery}

〈Original Articles〉

* 1) Gyoda Y, Imamura H, Ichida H, Yoshimoto J, Ishizaki Y, Kuwatsuru R, Kawasaki S: Significance of hypovascular lesions on dynamic computed tomography and/or gadolinium ethoxybenzyl diethylenetriamine pentaacetic acid-enhanced magnetic resonance imaging in patients with hepatocellular carcinoma. J Gastroenterol Hepatol, Epub 2018 Nov 9.

2) Oguro S, Yoshimoto J, Imamura H, Ishizaki Y, Kawasaki S: Clinical significance of macroscopic no-margin hepatectomy for hepatocellular carcinoma. HPB (Oxford), 2018; 20: 872-880.

$\langle$ Reviews〉

1) Takeda $Y$, Mise $Y$, Ishizuka N, Harada $S$, Hayama $\mathrm{B}$, Inoue $\mathrm{Y}$, Ishizawa $\mathrm{T}$, Ito $\mathrm{H}$, Takahashi Y, Saiura A: Effect of early administration of coagulation factor XIII on fistula after pancreatic surgery: the FIPS randomized controlled trial. Langenbecks Arch Surg, 2018; 403: 933-940.

2) Osumi H, Shinozaki E, Takeda Y, Wakatsuki $\mathrm{T}$, Ichimura T, Saiura A, Yamaguchi K, 
Takahashi S, Noda T, Zembutsu H: Clinical relevance of circulating tumor DNA assessed through deep sequencing in patients with metastatic colorectal cancer. Cancer Med, Epub 2018 Dec 21.

\section{Department of Gastroenterology and Minimally Invasive Surgery}

〈Original Articles〉

* 1) Ishibashi Y, Fukunaga T, Mikami S, Oka S, Kanda S, Yube Y, Kohira Y, Enomoto T, Otsubo T: Triple-stapled quadrilateral anastomosis: a new technique for creation of an esophagogastric anastomosis. Esophagus, 2018; 15: 88-94.

2) Nakamura Y, Yamanaka T, Chin K, Cho H, Katai H, Terashima M, Misawa K, Hirao M, Yoshida K, Oki E, Sasako M, Emi Y, Bando H, Kawashima Y, Fukunaga T, Gotoh M, Ishibashi T, Shitara K: Survival Outcomes of Two Phase 2 Studies of Adjuvant Chemotherapy with S-1 Plus Oxaliplatin or Capecitabine Plus Oxaliplatin for Patients with Gastric Cancer After D2 Gastrectomy. Ann Surg Oncol, Epub 2018 Nov 19.

3) Fukunaga T, Ishibashi $Y$, Oka S, Kanda S, Yube Y, Kohira Y, Matsuo Y, Mori O, Mikami S, Enomoto T, Otsubo T: Augmented rectangle technique for Billroth I anastomosis in totally laparoscopic distal gastrectomy for gastric cancer. Surg Endosc, 2018; 32: 40114016.

4) Wu JZ, Fukunaga T, Oka S, Kanda S, Ishibashi Y, Yube Y, Shen GH: Comparative study of outcomes of Roux-en-Y reconstruction and Billroth I reconstruction performed after radical distal gastrectomy. Asian J Surg, Epub 2018 May 24.

5) Yoshida N, Inaki N, Doyama H: Laparoscopic endoscopic cooperative surgery for gastric cancer with severe fibrosis. Dig Endosc, 2018; 30 Suppl 1: 32-33.

6) Kitamura H, Kurokawa M, Inaki N, Bando H: Gallbladder Metastasis from Renal Cell Carcinoma. Indian J Surg, 2018; 80: 278-280.

7) Zhang S, Du T, Yan D, Jiang X, Song C: A modified uncut roux $^{-} \mathrm{en}-\mathrm{y}$ anastomosis in laparoscopic-assisted distal gastrectomy: Balance of the cost and minimally invasion.
Transl Surg, 2018; 3: 1-5.

8) Zhang S, Yang Y, Yan D, Yuan B, Jiang X, Song C: Internet videos and colorectal cancer in mainland China: a content analysis. BMC Med Inform Decis Mak, 2018; 18: 129.

\section{Department of Breast and Endocrine Surgery}

$\langle$ Original Articles〉

1) Watanabe $T$, Yagata $H$, Saito $M$, Okada $H$, TYajima T, Tamai N, Yoshida Y, Takayama $\mathrm{T}$, Imai $\mathrm{H}$, Keiko Nozawa $\mathrm{H}$, Sangai $\mathrm{T}$, Yoshimura A, Hasegawa Y, Yamaguchi T, Shimozuma K, Ohashi Y: A multricenter survey of temporal changes in chemotherapy-induced hair loss in breast cancer patients. PLOS ONE, 2019; 14: e0208118.

2) Taguchi R, Okude $Y$, Saito M: What causes patients with breast cancer to change employment?: evidence from the health insurance data in a medical facility. Ind Health, Epub 2018 Aug 11.

3) Nakai K, Xia W, Liao HW, Saito M, Hung MC, Yamaguchi H: The role of PRMT1 in EGFR methylation and signaling in MDA-MB-468 triple-negative breast cancer cells. Breast Cancer, 2018; 25: 74-80.

4) Yamaguchi H, Du Y, Nakai K, Ding M, Chang SS, Hsu JL, Yao J, Wei Y, Nie L, Jiao S, Chang WC, Chen CH, Yu Y, Hortobagyi GN, Hung MC: EZH2 contributes to the response to PARP inhibitors through its PARP-mediated poly-ADP ribosylation in breast cancer. Oncogene, 2018; 37: 208-217.

5) Horimoto $Y$, Tokuda E, Murakami F, Uomori T, Himuro T, Nakai K, Orihata G, Iijima K, Togo S, Shimizu H, Saito M: Analysis of circulating tumour cell and the epithelial mesenchymal transition (EMT) status during eribulin-based treatment in 22 patients with metastatic breast cancer: a pilot study. J Transl Med, 2018; 16: 287.

6) Horimoto $Y$, Tanabe M, Kazuno S, Miura Y, Mogushi K, Sonoue H, Arakawa A, Kajino K, Kobayashi T, Saito M: Elucidation of inhibitory effects on metastatic sentinel lymph nodes of breast cancer during One-Step Nucleic Acid Amplification. Sci Rep, 2018; 8: 7563.

7) Okazaki M, Horimoto Y, Tanabe M, Ichikawa 
Y, Tokuda E, Arakawa A, Kobayashi T, Saito M: Predictive markers for efficacy of everolimus plus exemestane in patients with luminal HER2-negative metastatic breast cancer. Med Oncol, 2018; 35: 48.

8) Horimoto Y, Hirashima T, Arakawa A, Miura $\mathrm{H}$, Saito M: Metastatic colonic and gastric polyps from breast cancer resembling hyperplastic polyps. Surg Case Rep, 2018; 4: 23.

9) Sasaki R, Horimoto Y, Mizuno J, Edahiro Y, Ohmori T, Komatsu N, Saito M: Administration of plasma-derived coagulation factor VIII during the perioperative period of mastectomy for breast cancer with acquired von Willebrand syndrome. Surg Case Rep, 2018; 4: 118.

10) Yoshida-Ichikawa $Y$, Tanabe M, Tokuda E, Shimizu H, Horimoto Y, Miura K, Saito M: Overcoming the Adverse Effects of Everolimus to Achieve Maximum Efficacy in the Treatment of Inoperable Breast Cancer: A Review of 11 Cases at Our Hospital. Case Rep Oncol, 2018; 11: 511-520.

\section{Department of Cardiovascular Surgery}

〈Original Articles〉

1) Mukaida H, Matsushita S, Inotani T, Nakamura A, Amano A: Continuous renal replacement therapy with a polymethyl methacrylate membrane hemofilter suppresses inflammation in patients after open-heart surgery with cardiopulmonary bypass. J Artif Organs, 2018; 21: 188-195.

2) Bahatyrevich N, Yang Q, Cavarocchi NC, Hirose H: Is hemodynamic transesophageal echocardiography needed for patients with left ventricular assist device? J Thorac Cardiovasc Surg, 2018; 155: 1071-1077.

3) Goldhammer JE, Dashiell JM, Davis S, Torjman MC, Hirose H: Use of provider debriefing to improve fast-track extubation rates following cardiac surgery at an academic medical center. Am J Med Qual, 2018; 33: 172-176.

4) Devasagayaraj R, Cavarocchi NC, Hirose H: Does acute kidney injury affect survival in adults with acute respiratory distress syndrome requiring extracorporeal membrane oxygenation? Perfusion, 2018; 33: 375-382.
5) Huang D, Cavarocchi N, Hirose H: Management of cardiac standstill on veno-arterial extracorporeal membrane oxygenation using a high flow strategy. AME Med J, 2018; 3: 110.

6) Tanaka D, Shimada S, Mullin M, Kreitler K, Cavarocchi N, Hirose H: What is the optimal blood pressure on veno-arterial extracorporeal membrane oxygenation? Impact of mean arterial pressure on survival. ASAIO J, Epub 2018 May 11.

7) Miyazaki S, Kuwaki K, Kajimoto K, Matsushita S, Dohi S, Yamamoto T, Hata H, Amano A: Independent Effect of Low Flow on Outcomes in Patients Undergoing Aortic Valve Replacement for Severe Aortic Stenosis. Circ J, 2018; 82: 2199-2205.

8) Mukaida H, Matsushita S, Kuwaki K, Inotani T, Minami Y, Saigusa A, Amano A: Timedose response of oxygen delivery during cardiopulmonary bypass predicts acute kidney injury. J Thorac Cardiovasc Surg, 2018 Nov 16.

\section{Department of General Thoracic Surgery}

〈Original Articles〉

1) Niho S, Ikeda N, Michimae H, Suzuki K, Sakai H, Kaburagi T, Yoshiya K, Minato K, Kato T, Okamoto H, Seto T, Hosomi Y, Shimizu K, Saito H, Tsuchida M, Kunitoh H, Tsuboi M, Takeuchi M, Watanabe K: Overall Survival Results of the Feasibility Study of Adjuvant Chemotherapy With Docetaxel Plus Cisplatin Followed by Long-term Single-agent Administration of S-1 in Patients With Completely Resected Non-Small Cell Lung Cancer: Thoracic Oncology Research Group (TORG) 0809. Am J Clin Oncol, 2018; 41: 1113-1117.

2) Asahina M, Fukumura Y, Mamat O, Saito T, Hayashi T, Uekusa T, Suzuki K, Yao T: A case of combined small cell lung carcinoma with unique morphology: Investigation of tumorigenesis. Pathol Int, 2018; 68: 618-623.

3) Hata K, Suzuki K, Hattori A, Matsunaga T, Takamochi K, Oh C: P2.17-14 How Should Positive Margin for Bronchial Stumps (R1) Be Evaluated in Patients Undergoing Bronchoplasty for Lung Cancer? J Thorac Oncol, 2018; 13: S857. 
4) Hirayama S, Fukui M, Hattori A, Takamochi K, Oh S, Suzuki K: P3.16-25 Impact of Diabetes Mellitus on Survival Outcome in Patients with Pathological Stage IA NonSmall Cell Lung Cancer. J Thorac Oncol, 2018; 13: S1012.

5) Matsunaga T, Suzuki K, Takamochi K, Oh S: P3.01-71 Results of Extended Resection in T4 Non-Small Cell Lung Cancer. J Thorac Oncol, 2018; 13: S894-S895.

6) Nakamura H, Ichikawa T, Nakasone $S$, Aokage K, Tsuboi M, Suzuki K, Ishii G: P2.09-25 Abundant Tumor Promoting Stromal Cells in Lung Adenocarcinoma with Hypoxic Regions. J Thorac Oncol, 2018; 13: S770.

7) Watanabe I, Hattori A, Takamochi K, Oh S, Suzuki K: P3.15-28 Prognostic Nutritional Index for Predicting Postoperative Complications After Surgery Thoracic Tumor Involving the Neighboring Structures. J Thorac Oncol, 2018; 13: S1001.

8) Watanabe Y, Fukui M, Matsunaga T, Takamochi K, Oh S, Suzuki K: P2.17-29 Is Collagen Vascular Disease-Associated Interstitial Lung Disease a High Risk for Lung Cancer Surgery? J Thorac Oncol, 2018; 13: S864.

9) Hattori A, Matsunaga T, Takamochi K, Oh S, Suzuki K: Significance of Lymphadenectomy in Part-Solid Lung Adenocarcinoma: Propensity Score Matched Analysis. Ann Thorac Surg, 2018; 106: 989-997.

10) Hayashi T, Takamochi $K$, Yanai $Y$, Mitani $K$, Tomita H, Mogushi K, Suehara Y, Takahashi F, Suzuki K, Saito T, Yao T: Non-small cell lung carcinoma with diffuse coexpression of thyroid transcription factor-1 and $\Delta \mathrm{Np} 63 /$ p40. Hum Pathol, 2018; 78: 177-181.

11) Kawagoe I, Hayashida M, Satoh D, Suzuki K, Inada E: Ventilation failure after lateral jackknife positioning for robot-assisted lung cancer surgery in a patient after lingulasparing left upper lobectomy. JA Clin Rep, 2018; 4: 51.

12) Ueda $T$, Aokage $K$, Nishikawa $H$, Neri $S$, Nakamura H, Sugano M, Tane K, Miyoshi T, Kojima M, Fujii S, Kuwata T, Ochiai A, Kusumoto M, Suzuki K, Tsuboi M, Ishii G: Immunosuppressive tumor microenviron- ment of usual interstitial pneumonia-associated squamous cell carcinoma of the lung. J Cancer Res Clin Oncol, 2018; 144: 835-844.

13) Komori $K$, Hattori $A$, Matsunaga $T$, Takamochi K, Oh S, Suzuki K: Feasibility of surgery for pulmonary aspergilloma: analysis of the operative modes. Gen Thorac Cardiovasc Surg, 2018; 66: 276-283.

14) Hattori A, Suzuki K: New era defining a novel clinical T staging in non-small cell lung cancer. J Thorac Cardiovasc Surg, 2018; 155: 2179-2180.

15) Ichikawa T, Aokage K, Sugano M, Miyoshi T, Kojima M, Fujii S, Kuwata T, Ochiai A, Suzuki K, Tsuboi M, Ishii G: The ratio of cancer cells to stroma within the invasive area is a histologic prognostic parameter of lung adenocarcinoma. Lung Cancer, 2018; 118: $30-35$.

16) Takamochi K, Nojiri S, Oh S, Matsunaga $T$, Imashimizu K, Fukui M, Suzuki K: Comparison of digital and traditional thoracic drainage systems for postoperative chest tube management after pulmonary resection: A prospective randomized trial. J Thorac Cardiovasc Surg, 2018; 155: 1834-1840.

17) Ueda $T$, Suzuki K, Matsunaga $T$, Takamochi $\mathrm{K}$, Oh S: Postoperative atrial fibrillation is less frequent in pulmonary segmentectomy compared with lobectomy. Gen Thorac Cardiovasc Surg, 2018; 66: 95-100.

18) Ueda T, Suzuki K, Matsunaga T, Takamochi $\mathrm{K}$, Oh S: Correction to: Postoperative atrial fibrillation is less frequent in pulmonary segmentectomy compared with lobectomy (vol 66, pg 95, 2018). Gen Thorac Cardiovasc Surg, 2018, 66: 101-102.

19) Nakamura H, Ichikawa $T$, Nakasone $S$, Miyoshi T, Sugano M, Kojima M, Fujii S, Ochiai A, Kuwata T, Aokage K, Suzuki K, Tsuboi M, Ishii G: Abundant tumor promoting stromal cells in lung adenocarcinoma with hypoxic regions. Lung Cancer, 2018; 115: 5663.

〈Reviews〉

1) Suzuki K: Extended Sleeve Resection for Lung Cancer. Thorac Surg Clin, 2018; 28: 291-297. 